\title{
Nesneleştirilmiş Beden Bilinci Ölçeği-Genç Formunun Türkçeye Uyarlanarak Kendini Nesneleştirmenin Sosyal Medya Kullanımı ve Beğenilme Arzusu Arasındaki İlişkide Aracı Rolünün İncelenmesi
}

\author{
Adaptation of Objectified Body Consciousness Scale for Youth to \\ Turkish and to Investigate the Mediator Role of Self Objectification In \\ the Relationship Between Social Media Usage and Desire to be Liked \\ Sevgi ÖZGÜNGÖR*, Ahu ARICIOĞLU**
}

• Geliş Tarihi: 27.03.2019 • Kabul Tarihi: 18.01.2020• Çevrimiçi Yayın Tarihi: 28.01.2020

\begin{abstract}
Öz
Kendini nesneleştirme, bireyin değerinin fiziksel çekicilik ve güzelliğe bağlı olduğuna ilişkin kültürde yer alan ipuçlarının birey tarafından içselleştirilerek bu standartları kendi kendine dayatma sürecini ifade eder. Günümüzün popüler kültüründe gittikçe artan sayıda ergende kendini nesneleştirme ve bunun sonucu gelişen depresyon ve kaygı bozuklukları gibi sorunlar görülmektedir. Bu çalışma iki alt bölümden oluşmaktadır. Çalışmanın ilk bölümünün amac1 erken ergenlerde kendini nesneleştirme düzeyini ölçmeye yönelik olarak Lindberg, Hyde ve McKinley (2006) tarafından geliştirilen nesneleştirilmiş beden bilinci ölçeği-genç formunun Türkçe uyarlamasını yapmaktır. Bu çalışmanın ikinci bölümü kişileri kendini nesneleştirmeye yönelten sosyal ipuçlarının çokça var olduğu sosyal medyayı yüksek düzeyde kullanmanın, beğenilme arzusundaki artışla ilişkili olacağı ve bu ilişkide kendini nesneleştirmenin aracı rolü olduğu varsayımını test etmeyi amaçlamaktadır. Araştırmanın örneklemini ölçek geliştirme çalışma kapsamında 551, sosyal medya ve beğenilme arzusu ile ilişkilerini test etmek amacıyla 164 olmak üzere, toplamda 715 ortaokul öğrencisi oluşturmaktadır. Ölçeğin uyarlama çalışmaları kapsamında gerçekleştirilen veri analizleri orijinal ölçek yapısına uygun olarak toplam varyansın \%59'unu açıklayan 3 faktörlü yapıyı destekler niteliktedir. Ölçeğin beden izleme, kontrol inancı ve beden utancı alt ölçeklerine ait iç tutarlılık katsayıları sırasıyla .82, .72 ve .81'dir. Ölçeğin ölçüt geçerliliği kapsamında Rosenberg Benlik Saygısı ve Görünüm Kaygısı Ölçeği ile ilişkileri beklendik yönde ve anlamlıdır. Araştırmanın ikinci amacına yönelik regresyon analiz sonuçları, kendini nesneleştirmenin beden izleme ve beden utancı alt boyutlarının sosyal medya ile beğenilme arzusu arasındaki ilişkide aracı rolünü destekler niteliktedir.
\end{abstract}

Anahtar sözcükler: Erken ergenlik, kendini nesneleştirme, beğenilme arzusu, sosyal medya kullanım sıklığı.

Atıf:

Özgüngör, S., ve Arıcıoğlu, A. (2020). Nesneleştirilmiş Beden Bilinci Ölçeği-Genç Formunun Türkçeye uyarlanarak kendini nesneleştirmenin sosyal medya kullanımı ve beğenilme arzusu arasındaki ilişkide aracı rolünün incelenmesi. Pamukkale Üniversitesi Eğitim Fakültesi Dergisi,50, 23-49. doi: 10.9779/pauefd.544809.

\footnotetext{
* Prof, Pamukkale Üni. Eğitim F. Eğitim Bil. Böl., sozgungor @ pau.edu.tr, https://orcid.org/0000-0003-4954-1572

** Doç, Pamukkale Üni. Eğitim F. Eğitim Bil. Böl., aaricioglu @pau.edu.tr, https://orcid.org/0000-0002-1068-1175
} 


\begin{abstract}
Self-objectification refers to the process of self-imposing internalized cultural standards regarding a person's worth comes from his/her physical attractiveness and beauty. In today's popular culture, a growing number of adolescents have problems such as objectification and the related problems such as depression and anxiety disorders. This study has two components. The first part of the study aims to adapt Objectified Body Consciousness-Youth scale developed by Lindberg, Hyde, and McKinley (2006) to Turkish for preadolescent youth. The second part of this study aims to test the assumption that the use of social media with full of objectification cues will be related to self-objectification, and self-objectification in turn will be related to the desire to be liked further since self-objectification requires approval of others to feel confidence. The sample of the study consists of 718 secondary school students in total. The participators of the first part of the study, which is the adaptation phase, were 551 middle school students. The second part was conducted with 164 middle school students. The analyses of the data support the 3-factor structure explaining $59 \%$ of the total variance, which was similar to the original scale structure. The internal consistency coefficients of the scale for body surveillance, control belief and body shame subscales were .82, .72 and .81, respectively. Its' relationships with Rosenberg Self-Esteem and Social Appearance Anxiety Scale are meaningful and at the expected direction. Finally, the analysis run in the second part of the study confirmed the mediator role of body surveillance and body shame subscales of self objectification in the relationship of social media usage frequency and desire to be liked.
\end{abstract}

Keywords: Pre-adolescence, self-objectification, desire to be liked, social media usage frequency.

Cited:

Özgüngör, S., \& Arıcıoğlu, A. (2020). Adaptation of Objectified Body Consciousness Scale for youth to Turkish and to investigate the mediator role of self-objectification in the relationship between social media usage and desire to be liked. Pamukkale Üniversitesi Ĕgitim Fakültesi Dergisi, 50, 23-49. doi: 10.9779/pauefd.544809 


\section{Giriş}

Ergenlik, birçok alanda meydana gelen hızlı ve radikal yapısal değişimlerin yer aldığı gelişimsel bir fırsat dönemi olarak tanımlanabilir (Steinberg, 2014). Bu değişimlerin en önemlilerinden birisi cinsellik ve cinsel kimlik alanında gerçekleşir. Her ne kadar toplum kültürün belirlediği cinsiyet normlarını küçük yaşlardan itibaren bireye örtük bir şekilde sunsa da, kız/erkek çocuk statüsünden kadın/erkek olmaya uzanan ergenlik, fizyolojik ve kültürel olarak belirlenmiş bu rollerin yeniden tanımlanması ve benlik yapılandırılmasının bir parçası olarak içselleştirilmesi açısından büyük önem taşır. Bu nedenle, gelişmekte olan çocuk, toplumun diğer üyelerinin sunduğu norm ve beklentilere ve bu beklentileri karşılayıp karşılayamadığına ilişkin diğerlerinin sunduğu ipuçlarına karşı çok duyarlıdır. Ergenlik dönemine özgü bu duyarlılık, yeme bozuklukları ve depresyon gibi bazı gelişimsel sorunların artmasına neden olur (Canpolat, Orsel, Akdemir, Ozbay, 2005; Scales, 2010).

Ergenlikte bu tür problemlerle sıklıkla eşleştirilen bir kavram kendini nesneleştirme kavramıdır. Fredrickson ve Roberts (1997) tarafından geliştirilen kendini nesneleştirme kuramı, kendi değerinin fiziksel ve cinsel çekicilik düzeyiyle ölçülebileceğine ilişkin kültürün genel yargısını bireyin içselleştirerek toplumun değer ve beklentilerini kendi kendine dayatmaya başlaması sürecini içerir. Kendini nesneleştirme teorisine göre bir bireyin güzelliği ve çekiciliği için değerli olduğuna ilişkin açık ve örtük ipuçları ile donatılmış toplum, gençlere bedenlerinin bir zevk aracı olarak başkalarının değerlendirmelerine açı olduğunu öğretir. Bu tür değer ve beklentileri karşılamaya yönelik bir baskı ortamında yetişen birey, kendi değerinin fiziksel görünümüne, inceliğine ve cinsel çekiciliğine bağlı olduğuna yönelik bu değerlere herhangi bir baskı olmaksızın uymaya başlayarak dışarıdan kendini kontrol eden "üçüncü bir göze" dönüşür (Fredrickson ve Roberts, 1997). Kişinin ana odağının başkalarının gözünde daha güzel ve takdim edilebilir olmaya başlaması, bireyin kişisel kaynaklarının cinsel özgürlük, entelektüel ve duygusal eylemler gibi psiko-sosyal bütünlüğe yönelik eylemlerin kısıtlanmasına neden olur. Vücut fonksiyonel bir bütünden ziyade parçalar olarak algılanmaya başlandığında, bireylerin sağlıklı beden-ruh ilişkisi zedelenerek otantik ve üretken bir benliğin işlevselliği bozulur. Hem erkekler hem de kadınlar bu tür güzellik standartlarına ve normlarına tabi olsalar da, bu baskının daha yoğun olduğu kadınlarda bu durumun olumsuz etkilerinin daha belirgin olduğu yaygın olarak kabul edilmektedir (Calogero, 2012).

Mevcut çalışmalar, kendini nesneleştirmenin tıkınırcasına veya kısıtlayıcı yeme gibi yeme bozuklukları (Muehlenkamp ve Saris-Bağlama, 2002; Noll ve Fredrickson, 1998, Schaefer ve Thompson, 2018), iyilik hali (Breines, Crocker ve Garcia, 2008), benlik saygisı (McKinley ve Hyde, 1996, Mercurio ve Landry, 2008), olumsuz beden imgesi (Fitzsimmons-Craft ve Bardone-Cone, 2012, Strelan ve Hargreaves, 2005), yakın gelecekte estetik ameliyat yaptırma niyeti (Calogero, Pina, Park ve Rahemtulla, 2010) ve depresyon (Tolman, Impett, Tracy ve Michael, 2006) dahil olmak üzere pek çok farklı olumsuz değişkenle ilişkilerini ortaya koymuştur. Dahası, bu ilişkilerin nörotizm gibi kişilik bozukluklarının etkisi kontrol edildikten sonra bile anlamlı olduğu görülmektedir (Peat ve Muehlenkamp, 2011). Kendini nesneleştirme, yaşam kalitesini yakından etkileyen bu faktörlerin yanı sıra, içsel motivasyon ve bilişsel performans değişkenleriyle de ilintili bulunmuştur (Gapinski, Brownell ve LaFrance, 2003). Alan yazında sıkça atıf yapılan deneysel bir çalışmada Quinn, Kallen, Twenge ve Fredrickson 
(2006) kendini nesneleştirmenin bilişsel performans üzerindeki olumsuz etkisini test etmek amacıyla, katılımcılardan bazılarında kendini nesneleştirmeyi deneysel olarak sunulan ipuçları ile geçici olarak aktive etmişlerdir. Bu amaçla araştırmacılar katılımcılardan bazılarının mayo, bazılarının ise bol kazak giymelerini istemiş ve bilişsel bir testteki (stroop test) performanslarını karşılaştırmışlardır. Kuramın beklentileri doğrultusunda, testi mayo giyerek alan katılımcıların stroop testinde cevap verme sürelerinin daha uzun olduğu belirtilmiştir. Kendini nesneleştirmenin bireyin psikolojik ve bilişsel işlevselliği üzerindeki olumsuz etkilerinin ötesinde, toplumun sağlıklı işleyişine de zarar verebilecek nitelikte olduğunu gösteren çalışmalar da mevcuttur. Bernard, Legrand ve Klein (2018) üniversite öğrencilerine cinsel metalaştırmayı içeren ya da cinsellikle ilgili olmayan video klipleri izlettirdikten sonra görüntülerde tacize maruz kalan kurbanın yaşanan olaydaki rolüne ilişkin algılarını ölçmüşlerdir. Sonuçlar, sürekli (treyt) kendini nesneleştirme düzeyi arttıkça cinsel tacize karş1 hoşgörünün de arttığı şeklindedir; Kendini nesneleştirme puanları yüksek olan katılımcılar, taciz konusunda mağdurları daha fazla suçlayarak tacizi onaylamaktadırlar ve kendini nesneleştirme durumunda tacize ilişkin artan tolerans erkek katılımcılar için daha güçlüdür. Calogero (2013), hem korelasyona dayalı, hem de deneysel çalışmalar aracılığıyla, kadınlarda çevresel ipuçları ile (ör., mayo ile aynanın önünde oturarak) oluşturulan durumsal kendini nesneleştirme düzeyi artıkça katılımcıların cinsiyet temelli sosyal aktivizm etkinliklerine katılma isteklerinin de azaldığını ve cinsiyet temelli rollere daha fazla uyma eğilimde olduklarını göstermiştir.

Kendini nesneleştirme sürecinin gelişimini araştıran araştırmalar, kendini nesneleştirmenin 11 ila 80'ne uzanan yaş aralıklarındaki bireyleri kapsayan örneklemlerin hepsinde görülmesine rağmen (Calogero 2012), gençlerde, özellikle erken ergenlik döneminde çok daha belirgin olduğunu belirtmektedir (Hirschman, Impett ve Schooler, 2006). Ergenlerle yürütülen boylamsal bir çalışmada Impett, Henson, Breines, Schooler ve Tolman (2011), kendini nesneleştirme, öz saygı ve depresyon arasındaki ilişkileri analiz etmiş ve kendini nesneleştirme ve olumsuz etkilerinin 8 . sınıftan 12. sınıfa doğru azaldığını bildirmiştir.

Alan yazında, kendini nesneleştirme konusunda yapılan çalışmaların büyük bir kısmı Amerikalı ya da batılı kadın katılımcılarla gerçekleştirilmiş olduğundan farklı kültürel kökenlere sahip katılımcıları içeren kültürlerarası çalışmalara ilişkin ihtiyacın olduğu belirtilmiştir (örn., Moradi ve Yu-Ping, 2008). Sınırlı sayıdaki çalışmalar kendini nesneleştirme kuramının varsayımlarını özellikle kadınlar için destekler nitelikte olup dünyanın aşağı yukarı her yerinde insanların nesneleştirilmeye maruz kaldığ 1 ve örüntülerin benzer olduğunu ortaya koymaktadır (Calogero, 2012, Moya-Garofano, Megias, Rodriguez-Bailon, 2017, Harrison ve Fredrickson, 2003). Türkiye'de de farklı dergi ve reklam içeriklerini analiz eden çalışmalar reklamlarda yer alan kadın oyuncuların müstehcenlik ve cinsellik içeren, sadece dekor işlevli bir karakteri canlandırma oranlarının, hemen hemen her zaman giyinik ve çoğunlukla işle ilgili bir rolle temsil edilen erkek oyuncuların bu tür rollerde yer alma oranlarından daha fazla olduğunu göstermektedir (örn., Demir, 2006). Ergenin kişiliğini, değerlerini ve tutumlarını geliştirmedeki belirgin olumsuz etkilerine rağmen, bireyin cinsel nesneleștirilmesinin kültürel olarak artan oranda desteklenmesi ile birlikte bu eğilimin içselleştirilerek bireyin kendini nesneleştirme oranları da artmaktadır. Kültürün bu tür ipuçları aracılığıyla yarattığı olumsuz etkileri azaltmanın bir yolu, bu konuya ilişkin farkındalığı artırarak gençlerin güçlendirilmesi yanı sıra kendini nesneleştirmenin bireydeki olumsuz etkilerini yaratan ya da artıran koşul ve 
mekanizmaların belirlenmesidir. Ancak erken ergenlik ve ergenlik dönemindeki ergenler için Türkiye'deki mevcut durumu değerlendirmek için geçerli bir ölçüm aracı bulunmamaktadır.

Alan yazında, kendini nesneleştirmeyi ölçmek amacıyla sıklıkla kullanılan iki ölçüm aracı yer almaktadır. Noll ve Fredrickson (1998) tarafından sürekli kendini nesneleştirmeyi ölçmek için geliştirilen Kendini Nesneleştirme Ölçeği (KNÖ) (Self Objectification Questionnaire) ve McKinley ve Hyde (1996) tarafından geliştirilen Nesneleştirilmiş Beden Bilinci Ölçeği (NBBÖ) (Objectified Body Consciousness Questionnaire). Her iki araç da geçerli ve güvenilir bir ölçüm aracı olarak görülmekte ve Türkiye de dahil olmak üzere farklı kültürlerde yaygın olarak kullanılmaktadır (Doğan, 2013, Yağmurcu ve Tosun, 2018). Bununla birlikte, KNÖ nesneleştirmeye yönelik genel bir eğilimi ölçerken, NBBÖ hem sürekli, hem de günlük yaşamda yer alan ve araştırmacı tarafından da aktive edilebilen durumsal kendini nesneleştirmeyi de ölçebilmektedir (Lindberg, Hyde ve McKinley, 2006). Durumsal kendini nesneleştirme, bireyin mayo gibi bedeni ortaya çıkaran kıyafetler giydiğinde diğerlerinin bakışına maruz kalacağı kaygısını yaşadığ ettiği ve beden farkındalığının arttığı zamanlarda oluşan geçici nesneleştirmeyi tanımlamaktadır (Örn., Quinn ve ark., 2006). Daha da önemlisi, sadece NBBÖ, ön-ergen ve ergenlerin kendini nesneleştirme düzeylerini de değerlendirmek için yeniden düzenlenmiş sürümüne sahiptir. $\mathrm{Bu}$ çalışmanın ilk bölümünün amacı, Türk erken-ergenlerinin kendini nesneleştirme seviyeleri ve ilgili mekanizmaları ölçmeye olanak sağlayacak bir ölçüm aracının Türkçeye uyarlanmasıdır.

\section{ÇALIŞMA 1}

\section{Nesneleştirilmiş Beden Bilinci Ölçeği-Genç formunun Türkçeye Uyarlaması}

\section{Yöntem}

\section{Çalıșma Grubu}

Çalışmanın katılımcılarını Ege Bölgesindeki devlet okullarındaki altı, yedi ve sekizinci sınıfa devam eden gönüllü toplam 454 ortaokul öğrencisi oluşturmaktadır. Bu çalışmanın pilot çalışma aşamasında 97 (\%68 kız, \%32 erkek öğrenci) yedinci sınıf öğrencisine, uyarlama çalışmaları kapsamında ise 457 altı, yedi ve sekizinci sınıf ortaokul öğrencisine ölçekler sunulmuş ancak 2 öğrenci cinsiyetini belirtmediği ve 1 öğrenci yaşını 19 olarak belirttiği için örneklemden çıkarılmıştır. Nihai olarak uyarlama çalışmasının verileri $241 \mathrm{k} ı$ ve 213 erkek olmak üzere toplam 454 ortaokul öğrencisinden elde edilmiştir. Öğrencilerin yaşları 10 ile 15 arasında değişmekle birlikte büyük kısmı (\%88.4) 12-14 yaş aralığındadır ( $\overline{\mathrm{x}}=12.7)$. Öğrencilerin \%9’u 6. Sınıf, \%31'i yedinci sınıf ve \%60’1 8. sınıfa devam etmektedir.

\section{Veri Toplama Araçları}

\section{Nesneleştirilmiş beden bilinci ölçeği-genç formu (NBBÖ-genç formu) /OBC-youth scale}

NBBÖ-genç formu, beden izleme (4 madde), beden utancı (5 madde) ve kontrol inancı (5 madde) olmak üzere 3 alt ölçekten oluşmaktadır. Beden izleme, bireyin diğerlerinin önüne çıkılabilir ve güzel göründüğünden emin olmak amacıyla görünümünü sık sık kontrol etme alışkanlığını içerir. Beden utanc1, bir bireyin diğerlerinin kendisinden beklediği güzellik standartlarına erişememe konusundaki kaygı ve yetersizliğin yarattığı utanç duygusunun 
derecesini ölçer. Kontrol inanc1, bireylerin, bazen genetik kısıtlamalara rağmen, toplumun güzellik ideallerine ulaşmak için vücutlarının görünümü üzerinde kontrol sahibi olduğuna dair inancının derecesini ölçer. Lindberg ve ark. (2006) NBBÖ-genç formunu 10-12 yaş aralığındaki erken ergenlerden alınan verilerle geliştirmiş ve üniversite öğrencilerinden oluşan gençlerle de bulguları tekrar etmişlerdir. Araştırmacılar ölçeğin 10 yaş ve üzeri için geçerli ve güvenilir bir ölçme aracı olduğunu belirtmektedirler (Lindberg ve ark., 2006). NBBÖ-genç formu, 1(tamamen katılmiyorum) ve 7(tamamen katıliyorum) olarak belirlenen, yedili Likert tipi bir ölçektir. Alınan puan yükseldikçe, kendini nesneleştirme düzeyinin arttığı ifade edilmektedir. Ölçek tüm maddelerin toplamından oluşan kendini nesneleştirme düzeyini ölçmek amaciyla kullanılabildiği gibi alt boyutlar ayrı ayrı olarak da kullanılabilmektedir.

\section{Rosenberg benlik saygısı ölçeği}

Bu çalışmada, Rosenberg (1965) tarafından geliştirilen ve Çuhadaroğlu (1986) tarafından Türkçeye uyarlanan 63 maddelik ölçeğin 10 maddelik Benlik Saygısı boyutu kullanılmıştır. Rosenberg Benlik Saygısı Ölçeğinin alt boyutları için test tekrar test güvenirlik katsayısının .82 - .88 ve iç tutarlık katsayısının (Cronbach alpha) $.77-.88$ arasında değiştiği belirtilmiştir (Rosenberg, 1965). Bu çalışmada ölçeğin iç tutarlılık katsayısı .79'tur.

\section{Sosyal görünüş kaygısı ölçeği (SGKÖ)}

Hart ve ark. (2008) tarafından geliştirilen ve psikometrik özellikleri ergenlerden oluşan bir örneklemde de incelenen ölçek, Doğan (2010) tarafından Türkçeye uyarlanmıştır. 5'li Likert tipi ölçek, açımlayıcı ve doğrulayıcı faktör analizi sonuçlarına göre, özgün formunda olduğu gibi tek boyutlu bir yapıdadır. SGKÖ-E’nin Cronbach alfa iç tutarlık katsayısı .91 ve test tekrar test güvenirlik katsayısı .80 'dir. $\mathrm{Bu}$ çalışma için ölçeğin iç tutarlılık katsayısı .90 olarak belirlenmiştir.

\section{İşlem}

Çalışmanın ilk amacına yönelik işlemler 3 aşamada gerçekleştirilmiştir. Birinci aşamada, Dr. Lindberg'den ölçeğin Türkçede kullanım ve uyum çalışması için izin alındıktan sonra ölçek konu uzmanı olan ve İngilizce düzeyi yeterli iki araştırmacı tarafından önce Türkçeye, daha sonra tekrar İngilizceye çevrilerek dil eşdeğerliği sağlanmıştır. Ayrıca, çalışmanın amacına kör bir alan uzmanı, görünüş geçerliliği açısından maddeleri incelemiştir. Çalışmanın ikinci aşaması iki pilot çalışmadan oluşmaktadır. Birinci pilot çalışması sonrası ifadelerde bazı değişiklikler yapılmış ve ters kodlanan maddeler, ölçekteki diğer maddelerle korelasyonları düşük olduğundan olumlu ifade edilecek şekilde yeniden düzenlenmiştir. İkinci pilot çalışmada ölçeğin yeni hali farklı bir gruba sunulmuştur. Çalışmanın üçüncü aşamasında, pilot çalışması sonucu nihai şeklini alan 14 maddelik ölçekle birlikte ölçeğin ölçüt geçerliliğini belirlemek amacıyla Rosenberg'in Benlik Saygısı Ölçeği ve Görünüş Kaygısı ölçeği 457 kişilik yeni bir örneklem grubuna uygulanmıştır. Ölçeğin açımlayıcı ve doğrulayıcı faktör analizlerini gerçekleştirmek amaciyla verinin temizlenmesinden sonra kalan 454 veri random olarak ikiye bölünmüş ve analizler 2 ayrı örneklemle gerçekleştirilmiştir. Açımlayıcı faktör analizi $121 \mathrm{kız}$, 101 erkek, toplam 221 öğrenciden alınan veriler, doğrulayıcı faktör analizi ise 120 kız, 133 erkek öğrenci olmak üzere toplam 233 öğrenciden alınan verilerle yapılmıştır.

Ayrıca, ölçeğin test-tekrar test güvenilirliğini değerlendirmek için ilk uygulamadan 3 hafta sonra 100 öğrencilik bir alt gruba ölçek tekrar sunulmuştur. İkinci uygulamada bir öğrenci 
sınıfta bulunmadığından, test tekrar örneklem sayısı 99'a düşmüştür. Bu sayı Donner ve Eliasziw (1987) tarafindan açıklanan ölçütler çerçevesinde uygun kabul edilmektedir. Tüm ölçekler sınıf içinde, öğrencilere çalışmanın amacı açıklandıktan, herhangi bir soruları olup olmadığı sorulduktan ve sorular netleştirildikten sonra onam formları ile uygulanmıştır. Ölçek, alt ölçek ve ölçüt değişkenleri arasındaki korelasyon analizleri Pearson korelasyon katsayıları kullanılarak test edilmiştir. Ölçeğin ve alt ölçeklerin iç tutarlılı̆̆ını belirlemek için, Cronbach alfa katsayıları hesaplanmıştır. Faktör analizinde, alt faktörlerin birbirleriyle ilintili olması beklendiğinden eğik rotasyonlu temel faktör analizi (oblique) kullanılmıştır. Tüm istatistiksel analizler SPSS 21 ve Lisrel 8.80 ile yapılmıştır.

\section{Bulgular}

Geçerlik ve güvenirlik analizleri öncesinde, betimleyici istatistikler ve çalışma değişkenleri arasındaki korelasyonlar hesaplanmış ve değerler Tablo 1'de sıralanmıştır. Eldeki çalışmada kendini nesneleştirme düzeyi açısından cinsiyet farkı olup olmadığını belirlemek amacıyla bağımsız $\mathrm{t}$ testi yapılmıştır. Bulgular, kendini nesneleştirmenin beden izleme ve beden utancı alt boyutlarından alınan puanlar açısından literatüre paralel olarak kızların lehine cinsiyet farkı olduğunu ortaya koymuştur $\left(\bar{\chi}_{\mathrm{k} 1 \mathrm{Z}}=4.11, \mathrm{sd}=1.71, \bar{\chi}_{\text {erkek }}=3,67, \mathrm{ss}=1.59, \mathrm{t}(454)=2.85, \mathrm{p}<\right.$ .004 ve $\left(\bar{\chi}_{\mathrm{k} 1 \mathrm{z}}=3.21, \mathrm{sd}=1.61,\left(\bar{\chi}_{\text {erkek }}=2,83, \mathrm{sd}=1.58, \mathrm{t}(454)=2.56, \mathrm{p}<.011\right)\right.$. Makalenin bu bölümünün geri kalanı,geçerlilik ve güvenilirlik çalışmalarına yönelik analizlere ilişkin ayrıntıları içermektedir.

Tablo 1. Çalışmanın Değişkenlerine Ait Aritmetik Ortalama, Standart Sapma ve Korelasyon Katsayıları

\begin{tabular}{lcllll}
\hline & $\begin{array}{l}\text { Beden } \\
\text { İzleme }\end{array}$ & $\begin{array}{l}\text { Kontrol } \\
\text { İnanc1 }\end{array}$ & $\begin{array}{l}\text { Beden } \\
\text { Utanc1 }\end{array}$ & RBSÖ & SGKÖ \\
\hline Beden İzleme & 1 & $.32^{* *}$ & $.47^{* *}$ & $-.19^{* *}$ & $.44^{* *}$ \\
Kontrol İnanc1 & & 1 & $.14^{* *}$ & -.03 & $.15^{*}$ \\
Beden Utanc1 & & & 1 & $-.19^{* *}$ & $.51^{* *}$ \\
RBSÖ & & & & 1 & $-.29^{* *}$ \\
SGKÖ & 3.89 & 4.85 & 3.02 & 1.26 & 1 \\
$X$ & 1.67 & 1.37 & 1.60 & .59 & .87 \\
Ss & & & & & \\
& & & & & \\
\end{tabular}

Not: RBSÖ: Rosenberg Benlik Saygısı Ölçeği. SGKÖ: Sosyal Görünüş Kaygısı Ölçeği. $* \mathrm{p}<.05, * * \mathrm{p}<.01$

\section{Yapı Geçerliliği}

Geçerlik analizleri öncesi veriler eksik ve uç değerler ve normallik varsayımları açısından incelenmiştir. Analizler \% 5 'ten fazla eksik değere sahip maddenin ya da uç değerin bulunmadığını ve normallik varsayımlarının yerine getirildiğini ortaya koymuştur. Çarpıklık değerleri -1.21 ile .95 arasında, basıklık değerleri ise -1.74 ile .37 arasında değişmektedir ve bu değerler kabul edilebilir sınırlar olan -2 ve +2 aralığında bulunmaktadır (Chou ve Bentler, 1995). Z değerlerinin hiçbiri 3'ten yüksek değildir. Son olarak, çoklu normallik değerleri, kabul edilen kritik değer olan 20'nin altındadır (C. R.= 7.47) (Karagöz, 2016). 


\section{Açıklayıcı Faktör Analizi (EFA)}

Faktör analizinden önce, analiz için örneklem yeterliliğini belirlemek için Kaiser-Meyer-Olkind (KMO) katsayısı ve Barlett Küresellik (Sphericity) testi yapılmıştır (Kaiser, 1974). Bu çalışma için KMO değeri .84'tür ve Barlett Sphericity testi anlamlıdır $\left(X^{2}=973.81\right.$, sd $\left.=91, \mathrm{p}<.001\right)$. Bu sonuçlar örneklemin faktör analizi için gerekli ölçütleri karşıladığını göstermektedir. Faktör yapısını belirlemek amacıyla yapılan temel eksenler analizi sonrasında eğik (oblique) döndürme metodu öz değeri 1'den büyük 3 faktörlü bir çözüm ortaya koymuştur. Birinci faktör (Beden Utanc1) varyansın\% 31.2'sini açıklarken ikinci faktör (Kontrol inanc1) \%17.17'sini açıklamaktadır. Son olarak, Beden İzleme alt boyutu varyansın \%10,05'ini açıklamaktadır. On dört maddeden oluşan bu 3 faktör toplam varyansın \% 59'unu açıklamaktadır. Madde toplam korelasyonlarını belirlemek amacıyla Pearson momentler çarpımı korelasyon katsayıları hesaplanmıştır (Tablo 2). Cohen (1988) \pm .50 ila -1 ,arasındaki değerlerin yüksek, \pm .30 ila \pm .49 arası değerlerin orta ve \pm .10 ila \pm .29 arası değerlerin düşük korelasyon olarak tanımlanması gerektiğini belirtmiştir.

\section{Tablo 2. Nesneleştirilmiş Beden Bilinci Ölçeği- Genç Formuna Ait Faktör Yükleri}

\begin{tabular}{|c|c|c|c|c|}
\hline \multirow[b]{2}{*}{ Maddeler } & \multicolumn{4}{|c|}{ Faktör Yükleri } \\
\hline & $\begin{array}{l}\text { Beden } \\
\text { Utanc1 }\end{array}$ & $\begin{array}{l}\text { Kontrol } \\
\text { İnanc1 }\end{array}$ & $\begin{array}{l}\text { Beden } \\
\text { İzleme }\end{array}$ & $\begin{array}{l}\text { Madde Toplam } \\
\text { Korelasyonu }\end{array}$ \\
\hline 11. Diğerlerinin gerçek kilomu öğrenmesi beni utandırır. & .86 & & & .64 \\
\hline $\begin{array}{l}\text { 12.Formumu korumak için yeteri kadar çabalamıyorsam } \\
\text { kendimi kötü hissederim. }\end{array}$ & .84 & & & .65 \\
\hline $\begin{array}{l}\text { 13.Olmam gereken kiloda değilsem iyi görünmediğimi } \\
\text { düşünerek kendimden utanırım. }\end{array}$ & .83 & & & .55 \\
\hline $\begin{array}{l}\text { 10.En iyi şekilde görünmek için çabalamazsam utanç } \\
\text { duyarım. }\end{array}$ & .57 & & & .71 \\
\hline $\begin{array}{l}\text { 14.İyi görünmediğimi düşünüyorsam kendimi değersiz } \\
\text { hissederim. }\end{array}$ & .52 & & & .49 \\
\hline $\begin{array}{l}\text { 8. Yeteri kadar çabalarsam olmam gereken kiloda } \\
\text { olabileceğime inanıyorum. }\end{array}$ & & .77 & & .47 \\
\hline 9.İyi görünüp görünmemek bana bağlıdır. & & .76 & & .47 \\
\hline $\begin{array}{l}\text { 7.Kalıtımıma rağmen kilomu kontrol edebileceğimi } \\
\text { düşünüyorum. }\end{array}$ & & 69 & & .61 \\
\hline $\begin{array}{l}\text { 5.Eğer uğraşırsam istediğim kadar iyi görünebileceğimi } \\
\text { düşünüyorum. }\end{array}$ & & 69 & & .56 \\
\hline $\begin{array}{l}\text { 6.Vücudumun nasıl göründüğü konusunda kontrolüm } \\
\text { olduğuna inanıyorum. }\end{array}$ & & .64 & & .50 \\
\hline $\begin{array}{l}\text { 4.Diğer insanlara nasıl göründüğüm konusunda sıklıkla } \\
\text { endișelenirim. }\end{array}$ & & & -.85 & .70 \\
\hline 1.Nasıl göründüğümü sık sık diğerleriyle kıyaslarım. & & & -.82 & .66 \\
\hline $\begin{array}{l}\text { 2.Gün boyunca nasıl göründüğüm hakkında sıklıkla } \\
\text { düşünürüm. }\end{array}$ & & & -.77 & .75 \\
\hline $\begin{array}{l}\text { 3. Giydiğim kıyafetlerin beni iyi gösterip göstermediği } \\
\text { konusunda sıklıkla endişelenirim. }\end{array}$ & & & -.69 & .52 \\
\hline Toplam Özdeğer & & & 8.28 & \\
\hline Toplam Varyans & & & $\% 59.16$ & \\
\hline
\end{tabular}

Not: 3'ün altındaki faktör yükü değerleri belirtilmemiştir. 


\section{Doğrulayıcı Faktör Analizi (DFA)}

3 faktörlü yapının doğrulanması aşamasında LISREL 8.5 kullanılarak doğrulayıcı faktör analizi (DFA) yapılmış ve model parametreleri maksimum olasılık (ML) yöntemiyle tahmin edilmiştir (Jöreskog ve Sörbom, 2001). DFA'da eldeki modelin değerlendirilmesi amaciyla pek çok farklı uyum indeksi kullanılmaktaysa da, önerilen model ile eldeki örneklemin kovaryansının karşılaştırılmasında en yaygın olarak başvurulan uyum indeksleri ki-kare Uyum testi, Karşılaştırılmalı Uyum Endeksleri (CFI), Ortalama Hataların Karekökü (RMS veya SMRS) ve Yaklaşık Hataların Ortalama Kareköküdür (RMSEA) (Hu ve Bentler, 1999). Bu çalışmada kikare uyum indeksi, CFI, SMR ve RMSEA yanında, iyilik uyum indeksi (GFI) ve normale uygunluk indeksi (NFI) kullanılmıştır. CFI, GFI ve NFI için 0.95 ila 1.00 arasındaki değerler mükemmel, 0.90 ila 0.95 arasındaki değerler kabul edilebilir bir uyum göstergesi olarak kabul edilir (Hooper, Coughlan ve Mullen, 2008). RMR ve RMSEA endeksinin 0.05'ten az olması iyi bir model uyumunu gösterir; ancak 0.08 'den küçük değerler de kabul edilebilir. SRMR için kabul edilebilir değer.10'dan düşüktür (Hu ve Bentler, 1999; Tabachnick ve Fidell, 2001). Son olarak, manidar bir ki-kare değeri, gözlenen kovaryans değerleri ile tahmin edilen kovaryans değerleri arasında anlamlı bir farkın olduğu ve uyumun iyi olmadığına işaret etse de, ki-kare testinin örneklem büyüklüğüne duyarlılığı nedeniyle genellikle model fit endeksini belirlemek amacıyla $\chi 2$ değeri serbestlik derecesine bölünür. Bu oranın 3'ün altında olması genel olarak uyum göstergesi olarak kabul edilir (Tabachnick ve Fidell, 2001).

Doğrulayıcı faktör analizine göre modele ilişkin uyum istatistikleri kabul edilir düzeydedir $\left(\chi^{2}(74)=178.27, \mathrm{p}<.001, \chi 2 / \mathrm{df}=2.40, \mathrm{RMSEA}=0.079, \mathrm{CFI}=0.94, \mathrm{SRMR}=\right.$ $.073, \mathrm{GFI}=.90, \mathrm{NFI}=.91, \mathrm{AGFI}=.86)$. Tüm faktör yükleri istatistiksel olarak anlamlıdır. $\mathrm{Bu}$ sonuçlar ölçeğin Türkçe uyarlanmasını destekler niteliktedir (Şekil 1).

Lindberg ve ark. (2006) kontrol inancı alt boyutunun problemli olduğunu belirtmiş ve bu alt boyutun olmadığı 2 faktörlü modelin kullanımını önermiştir. Bu yüzden, DFA kapsamında iki faktörlü bir model de test edilerek 3 faktörlü model ile karşılaştırılmış ve uyum endeksleri Tablo 3'te listelenmiştir. Tablo 3'teki bulgular Lindberg ve arkadaşlarının önerileri doğrultusunda 2 faktörlü yapıya ait uyumun 3'lü yapıdan daha iyi olduğunu ancak her iki yapının da uyum indekslerinin kabul edilir düzeyde olduğunu ortaya koymaktadır.

Tablo 3. NBBÖ-Gençlik Formu DFA Uyum Endeksleri

\begin{tabular}{lccccccc}
\hline Model & $\mathrm{X}^{2}$ & $\mathrm{X}^{2} / \mathrm{Df}$ & NFI & CFI & GFI & RMSEA & SRMR \\
\hline İki Faktörlü Yapı & 46.33 & 1.78 & .98 & .97 & .95 & .059 & .0057 \\
Üç Faktörlü Yapı & -178.27 & 2.40 & .91 & .94 & .90 & .079 & .0073 \\
\hline
\end{tabular}

$* \mathrm{p}<0.001$ 


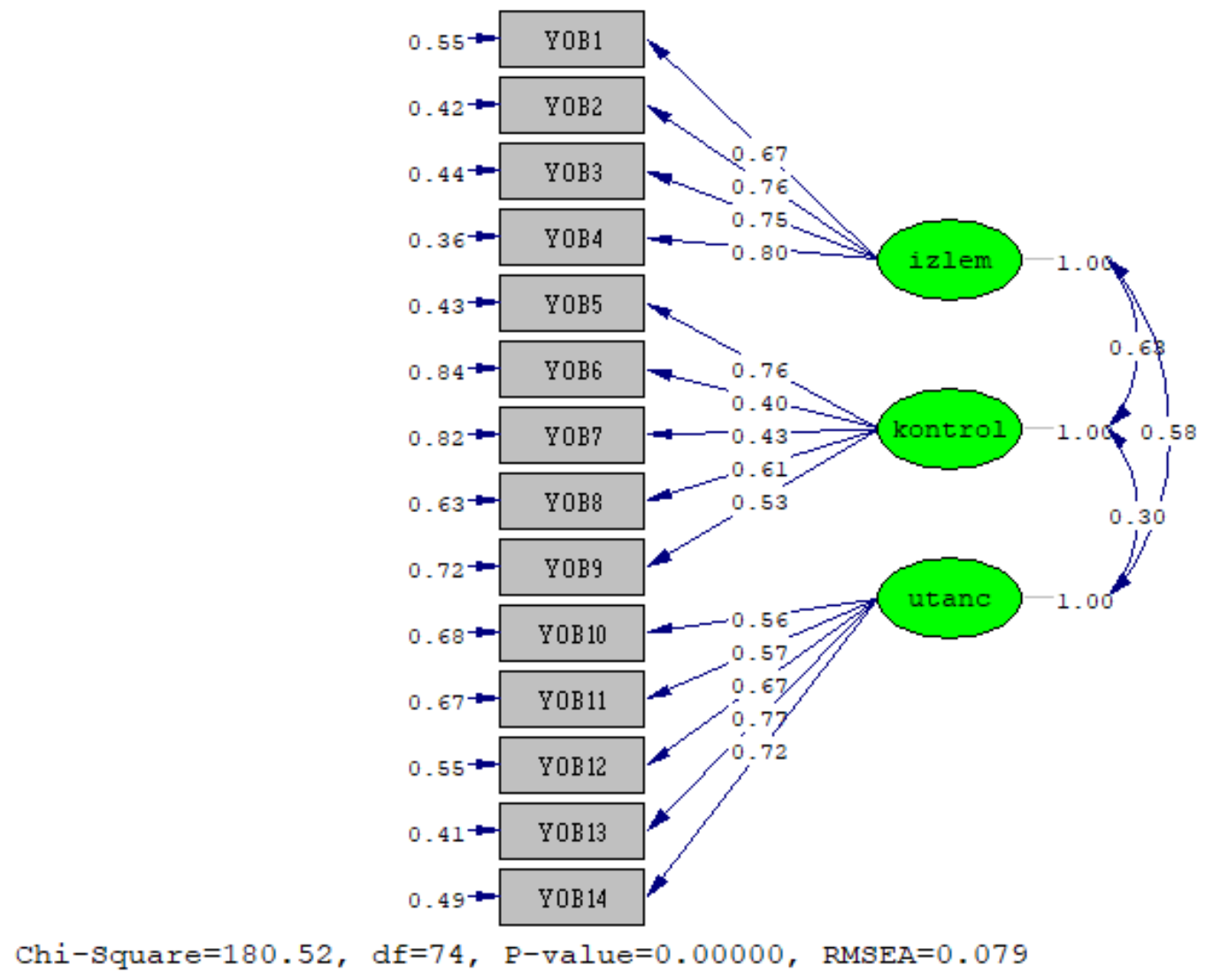

Şekil 1. Nesneleştirilmiş Beden Bilinci Ölçeği-Gençlik Formuna Yönelik DFA Sonuçları

\section{Ölçüt Geçerliliği}

Ölçüt geçerliliği ölçeğin aynı yapı veya büyük ölçüde ilişkili bir yapıya sahip başka bir ölçekle korelasyonunun hesaplanması aracılığıyla ölçülür. $\mathrm{Bu}$ çalışmada da, ölçüt geçerliliğ̈ini belirlemek amacıyla NBBÖ-Genç formu ile Rosenberg Benlik Saygısı Ölçeği-RSES ve Sosyal Görünüş Anksiyete Ölçeği (SGAS) arasındaki Pearson korelasyonları hesaplanmıştır. Kuramsal açıklamalara tutarlı olarak, beden izleme, beden utancı ve kontrol inancı alt ölçeklerinin sosyal görünüş kaygısı ile korelasyonları anlamlı ve olumlu yöndedir $(r=.43, \mathrm{p}<.001 ; r=.50, \mathrm{p}<.001$ ve $r=.20, \mathrm{p}<.001$, sırasıyla). Rosenberg Benlik saygısı ölçeğinin kontrol inancı ile korelasyonu anlamlı olmamakla birlikte, hem beden izleme ile $(r=-19, \mathrm{p}<.001)$, hem beden utancı $(r=-$ $.20, \mathrm{p}<.001)$ ile arasındaki korelasyon katsayıları olumsuz yönde anlamlı ve ölçeğin geçerliliğini destekler niteliktedir.

\section{Güvenilirlik Analizleri}

Ölçeğin güvenirliği iç tutarlılık katsayısı, test-tekrar test güvenirliği ve test yarı güvenirlik yöntemleri ile incelenmiştir. Öncelikle, NBBÖ-Genç formunun güvenilirliğini belirlemek için hesaplanan cronbach alfa katsayıları, beden izleme için .82, kontrol inanc1 için .72 ve beden utancı alt ölçeği için .81'dir. Tüm alt ölçekler için elde edilen değerler minimum kabul edilebilir değer olan .70'in üzerindedir (Kline, 2000). Bu değerler orijinal çalışmada rapor edilen değerlerden daha yüksektir. Olumlu yönde gözlenen bu farkın muhtemel nedeni, uyarlama 
çalışması sırasında ters maddelerin kullanılmamasıdır. Ölçeğin test yarı güvenirlik yöntemi ile elde edilen Guttman güvenirlik katsayısı, beden izleme için .82, kontrol inancı için .67 ve beden utancı alt boyutu için .77'dir. Son olarak, ölçeğin test-tekrar test güvenirlik katsayısını belirlemek amaciyla, ilk uygulamadan 3 hafta sonra 99 öğrenciden elde edilen verilere göre testin beden izleme, beden utancı ve kontrol inancı için test tekrar güvenirlik değerleri kabul edilebilir düzeydedir (sırasıyla, .81, .75 ve .60) (Karagöz, 2016).

\section{Tartışma}

Bu çalışmanın birinci bölümünden elde edilen bulgular, Nesneleştirilmiş Beden Bilinci Ölçeği Gençlik formunun erken ergenler için geçerli ve güvenilir bir ölçüm aracı olduğunu göstermektedir. Bu çalışmanın Türk erken ergenlere ait bulguları batı toplumlarında yaşayan ergenlerle yapılan çalışmaların sonuçlarına büyük oranda benzer nitelikte olsa da, bazı farklı1ıklar da bulunmaktadır. Benzerlikler açısından, ilk olarak, Lindberg ve diğerlerinin (2006) çalışmalarında ortaya konulan üçlü yapıya benzer bir yapı elde edilmiş ve özellikle kontrol inanc1 alt boyutuna ilişkin istatistiksel değerlerin eldeki örneklem için daha güçlü olduğu görülmüştür. Buna karşılık, yapısal olarak teorik varsayımlarla daha tutarlı olmasına rağmen, kontrol inanc1 alt ölçeğinin hem beden izleme hem de beden utancı alt ölçekleriyle, hem de sosyal görünüş kaygısı ölçüt değişkeniyle nesneleştirmenin diğer boyutlarından daha düşük korelasyona sahip olduğu ve benlik saygısı ile anlamlı bir ilişkisi olmadığı ortaya çıkmıştır. Bu sonuçlar, Lindberg ve arkadaşlarının beden izlenim alt boyutunun kendini nesneleştirmenin işlevsel olarak en önemli bileşeni olarak bireysel ve diğer alt ölçeklerle birlikte kullanılabileceği ve kontrol alt boyutunun kendini nesneleştirme konusunu anlamada diğer boyutlar kadar işlevsel olmadığına dair uyarılarını destekler niteliktedir (Lindberg ve ark. 2006). Araştırma sonuçları Nesneleştirilmiş Beden Bilinci Ölçeğinin erken ergenler için geçerli ve güvenilir bir ölçek olduğunu göstermekte ve ülkemizdeki konuya ilişkin çalışmalara ivme kazandırarak alan yazınının gelişmesine katkıda bulunacağı düşünülmektedir.

Bu bulgularla birlikte çalışmanın bazı sınırlılıkları vardır. Çalışmanın katılımcılarını Ege Bölgesindeki devlet okullarındaki altı, yedi ve sekizinci sınıfa devam eden gönüllü ortaokul öğrencileri oluşturduğu için, farklı örneklemlerde kullanılarak temsil edilebilirliğin arttırılması önerilebilir. Bundan sonraki çalışmalarda ölçeğin özellikle orta ergenler başta olmak üzere diğer yaş gruplarına da uygulanabilirliğinin test edilmesine yönelik araştırmalar yapılabilir.

\section{Çalışma II}

Bu çalışmanın ikinci bölümünde, kendini nesneleştirmenin sosyal medya kullanımı ile beğenilme arzusu arasındaki ilişkide aracı rolünü test etmek amaçlanmaktadır. Beğenilme arzusu, insanların kendilerini iyi hissetmeleri için diğerlerinin sevgi ve şefkatlerini kazanma ve başkalarından olumlu geribildirim ve onay almaya yönelik doğuştan gelen doğal bir ihtiyaçtır (Kaşıkara ve Doğan, 2017). Bununla birlikte, ergenlik değişen fiziksel, bilişsel ve psikososyal ihtiyaçlara paralel olarak benlikte ciddi yapılanmaların olduğu ve kimlik arayışının belirgin düzeyde arttığı bir dönemdir (Erikson, 1950). Bu durum, bireye kim ve nasıl bir birey olmas1 konusunda bilgi sağlayıcı niteliğinden dolayı başkaları tarafından onay ve beğeni almayı diğer dönemlere kıyasla daha önemli hale getirir (Kellough ve Kellough, 2008). Crow ve Crow (1956) ergenlerin kişiliğini belirleyen en önemli ihtiyaçlar arasında beğenilme ve takdir edilme 
isteğinin yer aldığını belirtmekte, Robinson (1995) ise diğerlerinin birey hakkındaki düşünce ve yorumlarının bireyin kim olduğuna dair his ve düşüncelerinin bir parçası haline gelerek benlik yapılanmasında rol oynadığını belirtmektedir. Benzer şekilde, Harter (1990), ergenlik döneminde diğerlerinin beğenisi aracılığıyla sunulan sosyal onay ve duygusal desteğin öz sayg1 düzeyinin en önemli belirleyicileri arasında yer aldığını belirtmektedir. Başkalarının beğenisi ve onayına karşı artan bu hassasiyet sonucu, özellikle ön erinlik döneminde, birey kendi görüşleri ile diğerlerinin birey hakkındaki görüşleri arasındaki fark ve eleştiriye karşı aşırı kırılgan hale gelir (Scales, 2010) ve ergen diğerlerinin beğenisi ve onayını almak ve dışlanmamak amacıyla riskli davranışlara yönelebilir (Jaffe, 1998). Bu konuda yapılan çarpıcı araştırmalardan birinde Constanzo (1970) Ash'in (1956) klasik haline gelmiş uyma çalışmasını yaşları 7 ile 21 arasında değişen 590 katılımcıyla tekrarlayarak uyma davranışının gelişimsel örüntülerini belirlemeyi amaçlamıştır. Constanzo, yerine getirilmesi son derece kolay olan bir görevde diğerlerinin yanlış cevap verdiğini düşündüklerinde kendileri de yanlış cevap verenlerin oranını yaş grubuna göre incelendiğinde diğerlerine uyma davranışının en fazla 12-13 yaşındaki erken ergenlik dönemindeki katılımcılar tarafından, ikinci olarak da orta ergenlik dönemindeki katılımcılar tarafindan gerçekleştiğini belirtmişlerdir. Bu çalışmayı takiben Insko, Drenan, Solomon, Smith ve Wade (1983) deneysel çalışmaları sonucunda gözlemlenen bu uyma davranışının diğerleri tarafından beğenilme ve doğru olma ihtiyaçlarına dayalı olduğunu belirtmişlerdir. Bu bulgular başkalarının beğeni ve onayının olumsuz etkilerinin özellikle erken ergenlik döneminde daha belirgin olduğunu ortaya koymaktadır. Bu yüzden bu dönemde ergenlerin gelişimsel olarak artan beğenilme arzusu ve ilgili mekanizmaların çalışılması ergen davranışlarını anlama açısından yararlı olacaktır.

Son yıllarda pek çok araştırmacı benlik ve kimlik inşasında sosyal medyanın kendine özgü rolüne vurgu yapmaya başlamıştır. Manago, Graham, Greenfield ve Salimkhaj (2008) sosyal medya platformlarından Myspace'in belirlenen sosyal etkileşim normları çerçevesinde öz sunuma dair farklı olası ve gerçek benlerin deneyimlenerek test edildiği bir kültür sunduğunu öne sürmektedirler. Yine aynı araştırmacılar, Festinger'in (1954) fiziksel gerçekliğin belirsiz olduğu durumlarda diğerlerinin fikirlerine daha bağımlı olunduğuna dair açıklamalarından yola çıkarak fiziksel olarak birebir karşılıklı etkileşimin olmadığı sosyal medyada bireylerin diğerlerinin onay ve beğenisinin daha çok önemsendiğini öne sürmüşlerdir. Benzer şekilde, Sherman, Payton, Hermandez, Greenfield ve Dapretto'ya (2016) göre sosyal medyada bireyler gerçekte oldukları kişiden bağımsız olarak olmak istedikleri veya olma ihtimalleri olan alternatif benleri kolayca sunabilirler. Bu durum, kimlik oluşumu sürecinde sunulan farklı olasıllıklar arasından diğerleri tarafından beğenilenlerin seçimini içerdiğinden diğerleri tarafından beğenilmeyi daha önemli kılabilir. Üstelik, online etkileşim ikili etkileşimlerden farklı olarak bireyin daha içsel ve karmaşık, kontrol edilmesi zor özellikleri yerine dıştan daha kolay fark edilebilen fiziksel özellikleri aracılığıyla beğeni toplamasının mümkün olduğu bir platformdur. Nitekim alanda sosyal medya kullanımı ile artan onay ve beğeni ihtiyacının olumsuz etkileri arasında ilişki kuran çalışmalar da mevcuttur. Mehdizadeh, (2010), insanların sosyal medyada kendilerini olumlu bir şekilde temsil etme eğiliminde olduklarını ve bu eğilimin sürekli olarak daha iyi ve yapay bir şekilde resmedilme rekabetini doğurduğunu bildirmiştir. Verduyn ve diğerleri, (2015) sosyal medyada olduğundan daha pozitif şekilde çarpitılmış paylaşım ve bildirimlerin, insanları sürekli kendilerinden daha iyi görünen diğerleriyle karşılaştırmaya zorlayarak genel iyilik halini azaltabileceğini bildirmiştir. Holland ve Tiegerman (2016) çocuk, 
erken ergenlik, ergenlik ve genç yetişkinlerin yer aldığı 20'den fazla çalışmayı gözden geçirdikleri derleme çalışmalarında genel olarak sosyal medya kullanımı ile artan olumsuz vücut imgesi ve yeme bozuklukları arasında pozitif ilişki olduğunu ve bazı çalışmaların bu ilişkinin sosyal kıyaslama kuramı (Festinger, 1954) çerçevesinde bireyin kendisi ve diğerlerini kıyaslamaya teşvik eden öz değerlendirme üzerinden olduğunu (Perloff, 2014), diğerlerinin ise kendini nesneleştirme (Fredrickson \& Roberts, 1997) üzerinden olduğunu savunduklarını belirtmişlerdir.

$\mathrm{Bu}$ çalışmada da sosyal medya kullanımının kendini nesneleştirmeyi teşvik ederek beğenilme arzusunu artıracağı varsayılmaktadır. Sosyal medya kullanımı hem kişiye ait olmayan gerçek dişı öz sunumlarla kolayca beğeni alabilme aracı olarak, hem de fiziksel görünüm ve çekicilik aracılı̆̆ ile başkalarından onay almayı sosyal bir norm haline getirerek ergenlerde kendini nesneleştirme ile ilişkili fiziksel çekicilik ve güzelliği ön plana çıkaran davranışları arttırabilir. Öz saygı ve onay kaynağının kendini nesneleştirme sonucu başkalarının beğenisine dayalı fiziksel çekicilik ve güzelliğe bağlı olması bireyin başarı, kişilik özellikleri, özel yetenekleri ve empati becerileri gibi kendine özgü diğer olumlu özelliklerinin bireyin benlikle ilgili değerlendirmelerinde ulaşılabilirliğini azaltarak diğerlerinin fikirlerine daha da bağımlı kılabilir. Katılımcılarını 10-12 yaş aralığındaki kızların oluşturduğu çalışmalarında Tiggemann ve Slater, (2014) internette harcanan sürenin ince bedene ilişkin ideallerin içselleştirilmesi, kendini nesneleştirme, diyet ve düşük öz-saygıyla ilişkili olduğunu ve sosyal ağlarda harcanan zamanın internette geçirilen süreden daha güçlü ilişkileri olduğunu rapor etmişlerdir. Cohen, Newton-John ve Slater (2017) genç kadınlarda sosyal medya kullanımı ile vücut algısı arasındaki ilişkileri test ettikleri çalışmalarında sosyal medyada öz çekim yapma ve paylaşma gibi etkinliklerin sıklığı ile vücut algısı problemleri ve yeme bozuklukları arasında ilişki saptamış ve bulimia semptomları ile özellikle öz çekim etkinlikleri arasındaki ilişkinin kendini nesneleştirme üzerinden olduğunu belirtmişlerdir. Sherman, Payton, Hermandez, Greenfield ve Dapretto (2016) online etkileşimlerin, kişilerarası ilişkilerin genellikle öznel çıkarımları içeren karmaşık yapısına tezat olarak farklı çıkarımlara olanak vermeyen basit etkileşimlerin daha fazla içerdiğini belirtmişlerdir. Bu özelliğinden dolayı online etkileşimleri özellikle gelişimsel olarak diğerlerinin onay ve beğenisine ihtiyacın yüksek olduğu ergenler için (Stemberg, 2008) 'beğen' tuşu aracılığıyla kolay elde edilebilir ve değerleri etkileyen güçlü bir motivasyon kaynağı olarak tanımlamışlardır. Bu savlarını test ettikleri çalışmalarında ergenlerin diğerleri tarafindan daha fazla beğeni alan fotoğrafları daha çok beğendiklerini ve bu etkinin beğenilen fotoğraf kendilerinin olduğunda daha fazla olduğunu bulmuşlardır. Dahası aynı araştırmacılar ergenlerin kendi fotoğraflarının beğenildiğini düşündüklerinde beynin ödül merkezlerinde daha fazla aktivasyonun tespit edildiğini bildirmişlerdir. Araştırmacılar bu bulguların ergenlikte öz sunumun öneminin göstergesi olduğunu belirtmişlerdir. Günümüzde sosyal medyanın en önemli kullanıcıları arasında erken ergenler ve ergenler yer almaktadır. $\mathrm{Bu}$ dönemde bireyler, çocukluktan yetişkinliğe geçiş dönemine özgü kimlik arayışı ve onay ihtiyacının bir sonucu olarak kendilerine ilişkin genellikle iyileştirilmiş ve gerçeği temsil etmeyen en iyi içerik ve fotoğraflarını içeren bildirimleri sık sık paylaşmaktadırlar. Bu yüzden, eldeki çalışmada yukarıdaki alan yazını 1şığında ergenlerin sosyal medya kullanım düzeylerindeki artışa paralel olarak başkaları tarafından beğenilme ihtiyacının ve kendini nesneleştirme düzeyinin de artması beklenmektedir. Alan yazında, bireyin kendini nesneleştirmesinin bireyin kendine ilişkin algıları ile ilgili olmaktan çok diğerlerinin bireye 
ilişkin olumsuz algılarının verdiği kaygıyı azaltma ve toplumun bireye ilişkin pozitif imajını beslemeye yönelik olduğu belirtilmektedir (Frederickson ve Roberts, 1997). Bu nedenle bu çalışmada, sosyal medya kullanımına paralel olarak artması beklenen beğenilme arzusuna ait varyansın bir kısmının, her zaman güzel ve iyi görünebilme gereksinimleriyle tanımlanan kendini nesneleştirme düzeyi ile açıklanabilir olması beklenmektedir. Özetle, çalışmanın bu kısmının amacı ergenlerde sosyal medya kullanımı ile beğenilme arzusu arasındaki olası ilişkide kendini nesneleştirme alt boyutlarının aracılık rolünü test etmektir.

\section{Yöntem}

\section{Çalışma Grubu}

Çalışmanın katılımcılarını Ege Bölgesindeki devlet okullarındaki altı, yedi ve sekizinci sınıfa devam eden toplamda 164 gönüllü 6., 7., ve 8. Sınıf ortaokul öğrencileri oluşturmaktadır. Öğrencilerin 82'si kız ve 82'si erkek öğrencidir. Öğrencilerin yaşları 11 ile 15 arasında değişmektedir $(X=12,40)$. Öğrencilerin \%70'i 6. Sınıf, \%12'si yedinci sınıf ve \%16’1 8. sınıfa devam etmektedir.

\section{Çalışmada Kullanılan Ölçme Araçları}

Nesneleştirilmiş beden bilinci ölçeği-genç formu (NBBÖ-genç formu) /OBC-youth scale

NBBÖ-genç formu, Lindberg, Hyde ve McKinley (2006) tarafından geliştirilen ve araştırmacılar tarafindan uyarlama analizleri yapılan 14 maddelik 7'li Likert tipi bir ölçektir ve beden izleme (4 madde), beden utancı ( 5 madde) ve kontrol inancı ( 5 madde) olmak üzere 3 alt ölçekten oluşmaktadır. Ölçeğin çalışmanın bu bölümünün katılımcılarından alınan verilere göre cronbach alfa katsayıları, beden izleme için .81, kontrol inanc1 için .65 ve beden utancı için .79 'dur.

\section{Beğenilme arzusu ölçeği}

Beğenilme arzusu ölçeği, Kaşıkara ve Doğan, (2017) tarafından geliştirilmiştir. 4'lü Likert tipi ölçeğin 9 maddelik toplam varyansın \%42'sini açıklayan tek faktörlü yapısı AFA ve DFA tarafından desteklenmiştir. Ölçeğin iç tutarlık katsayısı .81 olarak belirtilmiştir. Eldeki çalışmada ise iç tutarlılık katsayısı .77'dir.

\section{Sosyal medya kullanım sıklı̆̆}

Katılımcıların sosyal medya kullanım sıklıkları araştırmacılar tarafindan demografik bilgileri toplamak amacıyla hazırlanan kişisel bilgi formu aracılığıyla ölçülmüştür. $\mathrm{Bu}$ amaçla katılımcılara Facebook, Twitter, Myspace, Tumblr, Youtube ve Linkedln gibi sosyal medya sitelerini bir günde ortalama kaç saat kullandıklarını belirtmeleri istenmiştir.

\section{İşlem}

Çalışmanın ikinci amacına yönelik olarak sosyal medya kullanımı ile beğenilme arzusu arasındaki ilişkide kendini nesneleştirmenin aracı rolünü test etmek amacıyla Türkçe NBBÖ Genç formu ve Beğenilme Arzusu Ölçeği yanı sıra, cinsiyet, yaş ve günlük sosyal medya kullanım sıklıklarını (günlük kaç saat) ölçen maddeler 164 öğrenciden oluşan yeni bir örneklem grubuna sunulmuştur. Sosyal medya kullanımı ile beğenilme arzusu arasındaki ilişkide kendini 
nesneleştirmenin aracı rolü regresyon analizi ile gerçekleştirilmiştir ve tüm istatistiksel analizler SPSS 21 aracılığıyla yapılmıştır.

\section{Bulgular}

\section{Sosyal Medya Kullanımı ile Beğenilme Arzusu Arasındaki İlişside Kendini Nesneleștirmenin Aracı Rolüne Yönelik Bulgular}

Çalışmanın ikinci kısmı, kendini nesneleştirme, sosyal medya kullanımı ve beğenilme arzusu arasındaki ilişkileri ve bu potansiyel ilişkilerin kendini nesneleştirme alt boyutları tarafından açıklanıp açıklanamayacağını test etmeye yöneliktir. Bu amaçla, kendini nesneleştirmeye ait her bir alt boyut için aracılık testi ayrı ayrı gerçekleştirilmiştir. Sosyal medyanın kendini nesneleştirmeye yönelik ipuçlarının kızlar üzerindeki baskısının daha fazla olması nedeniyle sosyal medya sıklı̆̆ ile beğenilme arzusu arasındaki ilişkide kendini nesneleştirme alt boyutlarının aracı rolünün cinsiyet dikkate alındığında değişip değişmediğini belirlemek amacıyla tüm analizlerin son aşamasında cinsiyet kukla (dummy) değişken olarak analizlere dahil edilmiştir. Çalışma değişkenleri arasındaki korelasyonlar, aritmetik ortalamalar ve standart sapma puanları Tablo 4 'te verilmiştir.

Tablo 4. Değişkenlere Ait Aritmetik Ortalama, Standart Sapma ve Korelasyon Katsayıları

\begin{tabular}{lccccc}
\hline & $\begin{array}{c}\text { Beden } \\
\text { İzleme }\end{array}$ & $\begin{array}{l}\text { Kontrol } \\
\text { Inanc1 }\end{array}$ & $\begin{array}{c}\text { Beden } \\
\text { Utanc1 }\end{array}$ & $\begin{array}{l}\text { Beğenilme } \\
\text { Arzusu }\end{array}$ & $\begin{array}{l}\text { Sosyal } \\
\text { Medya } \\
\text { Kullanımı }\end{array}$ \\
\hline Beden İzleme & 1 & $.32^{* *}$ & $.45^{* *}$ & $.65^{* *}$ & $.29^{* *}$ \\
Kontrol İnanc1 & & 1 & $.24^{* *}$ & $.29^{* *}$ & $.15^{*}$ \\
Beden Utanc1 & & & 1 & $.55^{* *}$ & .14 \\
Beğenilme Arzusu & & & & 1 & $.18^{*}$ \\
Sosyal Medya Kullanımı & & & & & 1 \\
X & 3.81 & 5.04 & 2.83 & 2.07 & 5.30 \\
Ss & 1.68 & 1.31 & 1.55 & .59 & 1.57 \\
\hline
\end{tabular}

$* \mathrm{p}<.05, * * \mathrm{p}<.01$

Analizlere göre, kendini nesneleştirmenin tüm alt boyutları ile beğenilme arzusu arasındaki korelasyonlar anlamlıdır. Ayrıca, hem kontrol inancı hem de beden izleme alt 2ölçekleri sosyal medya kullanımı ile ilişkilidir. Beden izlemenin sosyal medya kullanım sıklığı ile beğenilme arzusu arasındaki ilişkide aracı rolünü test etmek amacıyla yapılan regresyon analizinin ilk basamağında medya kullanım sıklığı beğenilme arzusunun anlamlı bir yordayıcısıdır $\left(\beta=.18, \mathrm{R}^{2}\right.$ değişikliği = .034). Analizinin ikinci basamağında, beden izlemenin regresyona eklenmesi $\mathrm{R}^{2}$ de önemli bir değişikliğe neden olmuş (.38) ve aynı zamanda sosyal medya kullanım sıklığı beğenilme arzusunu yordama gücünü yitirmiştir. Analizin son basamağında cinsiyetin regresyona girmesi analiz sonuçlarını değiştirmemiştir. Kendini nesneleştirmenin beden utancı alt boyutunun aracı rolünü belirlemek amaciyla regresyonun birinci basamağında sosyal medya kullanım sıklığı analize girilmiştir. Bu basamakta sosyal medya kullanım sıklığı beğenilme arzusunu anlamlı bir şekilde yordamıştır $\left(\beta=.18, \quad \mathrm{R}^{2}\right.$ değişikliği $=$. 034). Regresyon analizinin ikinci basamağında, beden utancı değişkeninin regresyona girmesi $\mathrm{R}^{2}$ de anlamlı bir artışa sebep olmuş (.28) ve sosyal medya kullanım sıklığ beğenilme arzusunu yordama gücünü yitirmiştir. Cinsiyet değişkeninin regresyona girmesi sonuçları değiştirmemiştir. Kendini nesneleştirmenin üçüncü boyutu olan kontrol inancının aracı rolünü belirlemek amacıyla aynı işlemler tekrarlanmış ve regresyonun ilk basamağında sosyal 
medya kullanımının beğenilme arzusunun anlamlı bir yordayıcısı olduğu görülmüştür $(\beta=.18$, $\mathrm{R}^{2}$ değişikliği $\left.=.034\right)$. Analizin ikinci basamağında kontrol inancı değişkeninin denkleme girmesiyle sosyal medya kullanım sıklığı anlamlılığını yitirmiş ve kontrol inanacının beğenilme arzusunun manidar bir yordayıcısı olduğu görülmüştür. Son olarak cinsiyet regresyona girdiğinde sosyal medya kullanımının beğenilme arzusunu yordama gücünün yine anlamlı olduğu görülmektedir. $\mathrm{Bu}$ aşamada cinsiyet etkisini daha net görebilmek amaciyla SPPS bölünmüş dosya seçeneği (split file) ile analiz tekrarlanmıştır. Sonuçlar, erkek öğrencilerde sosyal medya kullanımının beğenilme arzusunu yordamadığını ve kız öğrencilerde sosyal medya kullanımının beğenilme arzusu üzerindeki etkilerinin kontrol inancı değişkeninin analize girmesiyle azaldığı ancak anlamlılığını sürdürdüğü şeklindedir. Sonuçlar Tablo 5'te verilmiştir.

Tablo 5. Sosyal Medya Kullanımı İle Beğenilme Arzusu Arasındaki İlişkide Kendini Nesneleştirmenin Aracı Rolüne İlişkin Regresyon Analizi Sonuçları

\begin{tabular}{|c|c|c|c|c|c|c|}
\hline \multirow{11}{*}{ 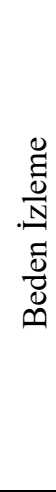 } & Değişkenler & B. & Std. Sapma & B & $\mathrm{T}$ & $\mathrm{P}$ \\
\hline & Basamak 1 & & & & & \\
\hline & Medya Kullanım Sıklığı & .07 & .03 & 18 & 2.38 & .02 \\
\hline & Basamak 2 & & & & & \\
\hline & Medya Kullanım Sıklığı & -.01 & .02 & -.01 & -.04 & .97 \\
\hline & Beden İzleme & .23 & .02 & .65 & 10.29 & .00 \\
\hline & Basamak 3 & & & & & \\
\hline & Medya Kullanım Sıklığı & -.01 & .02 & -.04 & -.06 & .95 \\
\hline & İzleme & .23 & .02 & .65 & 10.22 & 00 \\
\hline & Cinsiyet & .01 & .07 & .01 & .15 & .88 \\
\hline & $\begin{array}{l}\text { Basamak 1: } \mathrm{R}^{2} \text { Değ. }=.034, \mathrm{p}< \\
\text { 3: } \mathrm{R}^{2} \text { Değ. }=.001, \mathrm{p}<0.88\end{array}$ & $018, \mathrm{~B}$ & amak 2: $R^{2} I$ & ĕg. $=$. & $<<.001 \mathrm{~F}$ & samak \\
\hline \multirow{9}{*}{$\begin{array}{l}\overline{0} \\
\bar{\Xi} \\
\dot{D} \\
\overline{0} \\
\bar{D} \\
\infty\end{array}$} & Basamak 1 & & & & & \\
\hline & $\begin{array}{l}\text { Medya Kullanım Sıklı̆̆ } \\
\text { Basamak } 2\end{array}$ & .07 & .03 & 18 & 2.38 & .02 \\
\hline & Medya Kullanım Sıklı̆̆ 1 & .04 & .03 & .01 & 1.70 & .09 \\
\hline & Beden İzleme & .20 & .03 & .53 & 8.03 & .00 \\
\hline & Basamak 3 & & & & & \\
\hline & Medya Kullanım Sıklığı & .04 & .03 & .11 & 17 & .10 \\
\hline & Beden Utanc1 & .20 & .03 & .53 & 7.9 & .00 \\
\hline & Cinsiyet & -.01 & .08 & -.01 & -.10 & .92 \\
\hline & $\begin{array}{l}\text { Basamak 1: } \mathrm{R}^{2} \text { Değ. }=.034, \mathrm{p}<0.01 \\
\mathrm{R}^{2} \text { Değ. }=.001, \mathrm{p}<0.92\end{array}$ & \multicolumn{5}{|c|}{ Basamak 2: $\mathrm{R}^{2}$ Değ. $=.276, \mathrm{p}<.001$ Basamak 3: } \\
\hline \multirow{9}{*}{ 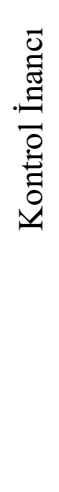 } & Basamak 1 & & & & & \\
\hline & Medya Kullanım Sıklığı & .07 & .03 & 18 & 2.38 & .02 \\
\hline & Basamak 2 & & & & & \\
\hline & Medya Kullanım Sıklığı & .05 & .03 & .14 & 1.90 & .06 \\
\hline & Kontrol İnanc1 & .12 & .03 & .27 & 3.62 & .00 \\
\hline & Basamak 3 & & & & & \\
\hline & Medya Kullanım Sıklığı & .06 & .03 & .15 & 1.99 & .05 \\
\hline & Kontrol İnanc1 & .12 & .03 & .28 & 3.65 & .00 \\
\hline & Cinsiyet & -.08 & .09 & -.07 & -.90 & .37 \\
\hline
\end{tabular}

\section{Tartışma}

Bu çalışmanın ikinci bölümünün amacı kendini nesneleştirmenin sosyal medya kullanımı ile beğenilme arzusu arasındaki ilişkide kendini nesneleştirme alt boyutlarının aracı rolünün test 
edilmesiydi. Yapılan analizler hem beden izleme boyutu, hem de beden utancı alt boyutlarının sosyal medya kullanım sıklığıyla ilişkili olduğunu ve sosyal medya kullanımı ile beğenilme arzusu arasındaki bu ilişkinin kendini nesneleştirme alt boyutları aracılığıyla olduğunu ortaya koymuştur. Hem beden izleme, hem de beden utancı alt boyutlarının analize girmesi sosyal medya kullanım sıklığının beğenilme arzusunu açıklayan varyansında önemli ölçüde düşmeye neden olmuştur. Üstelik bu bulgular cinsiyetin analize dahil edilmesiyle değişmemiş ve bulgular bu örüntülerin kız ve erkek öğrenciler için geçerli olduğunu ortaya koymuştur. Bu bulgular alan yazında sosyal medya kullanımının kendini nesneleştirmeyle ilişkilerini ortaya koyan çalışmaları (Cohen, Newton-John ve Slater, 2017; Meier ve Gray, 2013) desteklemekte ve ek olarak erken ergenlerde sosyal medya kullanımının kendini nesneleştirmeyi teşvik ederek gelişimsel olarak diğerlerinin onay ve beğenisine yönelik artan ihtiyacı daha da artırabileceğini ima etmektedir. Alan yazın ergenlerin diğerleri tarafindan onaylanma ve beğenilme ihtiyaçlarının kendine saygı (Harter, 1990) ve risk alma davranışları üzerindeki (Scales, 2010) olumsuz etkilerine dair bulgulara sahiptir. $\mathrm{Bu}$ tür arttırılmış beğenilme arzusunun sosyal medyanın baştan çıkaranları çerçevesinde olası zararları gelecek araştırmalarda ele alınması gereken bir konudur. Araştırmaya açık bir diğer konu ise yaşa bağlı olarak söz konusu bu ilişkilerin düzeyinin değişip değişmediğidir. Constanzo'nun (1970) diğerlerine uyma davranışının erken ergenlikte daha yüksek olduğu yönündeki bulgusuna dayalı olarak özellikle bu dönemde çocukların medyanın olumsuz mesajlarını içselleştirme konusunda daha hassas olduğu düşünüle bilinir. Aynı şekilde, bu dönemde medyanın olumsuz etkileri konusunda öğrencilere kazandırılacak farkındalık ve eleştirel düşünme becerileri bu olumsuz etkilere karş1 koruyucu olabilir. Gelecekte hem deneysel, hem korelasyona dayalı çalışmalar bu çalışmanın eksik bıraktığı bu konuları ele alabilir.

Beden izleme ve beden utancı alt boyutları sosyal medya kullanımı ile beğenme arzusu arasındaki ilişkide aracı rolüne sahipken, kontrol inancı alt boyutuna yönelik analizler erkek öğrencilerde sosyal medya kullanımının beğenilme arzusuyla ilişkisiz olduğu, kız öğrencilerde ise sosyal medya kullanımının beden kontrol alt boyutundan bağımsız olarak da beğenilme arzusuyla ilişkili olduğunu ortaya koymuştur. Bu bulgular araştırmanın sosyal medyada kendini nesneleştirme ipuçlarının bireye değerinin mükemmel görüntü aracılığıyla kolayca kazanılabilir inancı oluşturduğu şeklindeki beklentisini destekleyici niteliktedir. Kadınlara yönelik kozmetik reklamlar tüm vücut parçalarının doğru ürünle mükemmelleştirilebileceği inancını sunmakta ve sosyal medya bu inancı destekleyen pek çok örneği barındırmaktadır. Bu örneklerde sunulan standartlar içselleştirilerek dışarıdan beğeni kazanabilir fiziksel özelliklerin bireyin çabalarına bağlı olduğu inancı geliştiren ergenler sosyal medyadaki bu tür görüntülerle kendilerini daha sık kıyaslayarak rekabet ediyor olabilirler. Bu rekabet de diğerlerinin beğenisine olan ihtiyacı artırıyor olabilir. Bu tür bir baskının çok daha az olduğu erkek ergenler için ise sosyal medya kullanımının fiziksel çekiciliği kontrol ederek başkalarından beğeni toplama işlevine sahip olmadığı görülmektedir. Bu bulgular sosyal kıyaslama kuramının öngördüğü gibi sosyal medya kullanım sıklığının bireyi kendisini sosyal medya aracılığıyla sunulan diğerlerinin genellikle kusursuz ve çekici görüntüleriyle kıyaslamaya teşvik ederek beğenilme arzusunu tetiklediği görüşüyle paraleldir. Öte yandan, kontrol inancının kısmi aracılık rolü, erken ergenleri de kapsayan farklı yaş gruplarındaki kadınlarda sosyal medyada Facebook kullanımın sıklığı ve Facebookta kendi resimlerini yayınlama davranışlarının yeme bozukluklarıyla ilişkilerini ortaya koyan Holland ve Tiggemann'ın (2016) sistematik derleme çalışmasında belirtildiği gibi, sosyal 
medya kullanımının etkilerinin kendini nesneleştirmenin dışında mekanizmalarla da açıklanabileceği görüşüne destek vermektedir.

\section{Genel Tartışma ve Sonuç}

Günümüzün, popülerliği güzellik ve gücün belirlediği anlayışı çerçevesinde gittikçe daha fazla sayıda genç beyin toplumun gerçekçi olmayan güzellik standartlarını içselleştirerek kendini nesneleştirmektedir. Alan yazın depresyon, bilişsel becerilerin bozulması ve hatta taciz ve çocuğa saldırıya yönelik tolerans seviyelerinin artması dahil olmak üzere, kendini nesneleştirmenin geniş bir spektruma yayılan olumsuz etkilerini ortaya koymuştur. Bu çalışma, modelin öngördüğü, kendini nesneleştirmenin erken ergen ve ergenlerin kişiliği ve davranışları üzerindeki etkilerinin kapsam ve derecesini test etmek amacıyla Nesneleştirilmiş Beden Bilinci Ölçeği-Genç formunu kültürel olarak batı toplumlarından farklı özelliklere sahip Türk kültürüne uyarlamak amacıyla tasarlanmıştır. Türkiye'de, özellikle medya aracılığıyla gençlere yönelik sunulan kendini nesneleştirme ipuçlarının yaygın olmasına rağmen, toplum tarafından cinsel olarak pasif kalmayı, erdemli olmayı ve anneliği bir kadının benimseyebileceği olası diğer tüm rollerin üstünde tutmayı teşvik edici gibi tezat standartlar ve roller, eşit derecede teşvik edilmektedir. Kendini nesneleştirmeye tezat bu ipuçları hem yazılı hem sosyal medya tarafından dayatılan her zaman mükemmele ve iyi görünme zorunluluğunun yarattığı baskıya karş1 koruyucu bir işlev görebilir ya da tam aksine çelişkili mesajlara sürekli yoğun bir şekilde maruz kalmanın yarattığı bocalanma Türk ergenler üzerinde Batılı akranlarına kıyasla daha belirgin olumsuz etkiler yaratabilir. Bu çelişkiler nedeniyle, kendini nesneleştirme, Türk gençlerini, özellikle kızlarını, kimlik geliştirmeye yönelik çatışmaların yoğunlaşması veya genç zihinleri sosyal meselelere kayıtsız kalmaya teşvik etme gibi farklı mekanizmalar aracılığıyla etkileyebilir. Önceki çalışmalar, kendini nesneleştirmenin sosyal adalete yönelik algıyla olumsuz ilişkisini ortaya koymuştur (Calegore, 2013). Erkeklerin, evde birincil söz sahibi birey olduğu ve kadına yönelik şiddetin yaygın bir şekilde görüldüğü bir ülkede, bu tür olası riskleri belirleyici mekanizmaların ve bu mekanizmalara bağlı olarak önleyici uygulamaların geliştirilmesi büyük önem taşımaktadır. Bu çalışmanın sonuçları, Türk erken ergenleri için NBBÖ-Genç formunun geçerliliğini ve güvenilirliğini teyit etmekte ve bu konunun çalışılmasında geçerli ve güvenilir bir ölçüm aracı sağlayarak literatüre katkıda bulunmaktadır. Gelecekteki çalışmalar kendini nesneleştirmenin gelişmekte olan gencin iyilik hali, kendine zarar verme davranışı, kaygı düzeyi gibi değişkenler yanında kadına şiddet gibi sosyolojik olgularla ilişkilerini inceleyerek alan yazına katkıda bulunabilir.

NBBÖ-Gençlik ölçeğinin psikometrik özelliklerini doğrulamanın yanı sıra, bu çalışma sosyal medya kullanımı, kendini nesneleştirme ve beğenilme arzusu arasındaki ilişkiyi de test etmiştir. Her ne kadar medya kullanımı beğenilme arzusunun anlamlı bir yordayıcısı olsa da, kendini nesneleştirmenin beden izleme ve beden utancı boyutları regresyona girdiğinde, sosyal medya kullanımının beğenilme arzusunun anlamlı bir yordayıcısı olmadığı görülmektedir. Bu bulgular, gençler tarafından daha yüksek düzeyde sosyal medya kullanımının kendini nesneleştirme ile ilişkili olduğunu, kendini nesneleştirmenin de daha yüksek seviyede beğenilme arzusuyla ilintili olduğunu göstermektedir. Ayrıca, kendini nesneleştirme ile medya kullanımı ve beğenilme arzusu arası ilişkiler teorik açıklamalarla tutarlı olarak kızlar için daha belirgindir (örn., Frederickson ve Roberts 1997). Muhtemelen kızların ve erkeklerin sosyal medya kullanım davranışları farklı motivasyonlara sahip olduğu için erkek öğrenciler için 
sosyal medya kullanımı ile beğenilme arzusu arzusu arasındaki ilişki erkeklerde daha zayıftır. Daha önceki çalışmalar, kızların sosyal medya paylaşımlarında arkadaşlarıyla birlikte yer aldıkları fotoğraflarını seçerek arkadaşlık bağlarını geliştirmeyi hedeflerken, erkeklerin sosyal medyada daha çok teknoloji, spor ve mizah içeren resimler paylaşma eğiliminde olduğunu göstermiştir (Sveningsson Elm, 2007). Ayrıca, hem kadın hem de erkek genç katılımcıların, kızların çekiciliğini vurgulayan resimleri seçme olasılıklarının erkeklerden daha fazla olduğunu düşündükleri belirtilmektedir (Manago, Graham, Greenfield ve Salimkhan, 2008). Araştırmanın bulguları, hem kızların hem de erkeklerin kendilerini nesneleştirmelerinin başkaları tarafından beğenilme arzusunun artmasıyla ilgili olmasına rağmen, sosyal medya kullanımının kadının nesneleştirilmesinin içselleştirilmesinde daha etkili olduğunu göstermektedir. Bu sonuçlar, genç erişkinlerde medyada sunulan özellikle stereo tipik kadın görüntülerini içeren medya mesajlarını içselleştiren katılımcıların kendilerine ait baştan çıkarıcı müstehcen fotoğraflarını paylaşma olasılıklarının daha yüksek olduğunu ve bu durumun kadın katılımcılar için daha belirgin olduğunu tespit eden Kapidzic'in (2011) bulgularına paraleldir.

Eldeki çalışmanın mevcut çalışmalarla uyumlu bir başka bulgusu, kız ve erkek katılımcıların kendini nesneleştirme düzeyleri karşılaştırıldığında, hem beden izleme, hem de beden utancı açısından kızların anlamlı derecede yüksek puanlara sahip olduğu şeklindedir. Alan yazında, kendini nesneleştirme ipuçlarının kadın ve kız çocukları için daha belirgin olduğu ve bu nedenle kendini nesneleştirmenin kızlarda daha fazla olduğu kabul edilmektedir. Ancak, kontrol inancı ölçeği açısından cinsiyetler arasında bir fark yoktur. Hem kız, hem de erkek ergenlerde kontrol inancı puanları diğer kendini nesneleştirme boyutlarından daha yüksektir. Sonuçlar, her iki cinsiyetin de, yeterli bakım ile kadın ve erkeğin mucizevi bir şekilde "olağanüstü güzel bir varlığa" dönüştürüldüğü görüntülere maruz kalsa da, onlar gibi görünmeye ilişkin baskının ve bu baskının yarattığı gelişimsel sorunların kızlar için daha belirgin olduğu şeklinde yorumlanabilir.

Çalışma, artan sosyal medya kullanımının ergenlerin kendini diğerlerine ait hissetme (Barker, 2012) ve benlik oluşturma sürecinde bilgi toplama (Davis, 2013) gibi olumlu etkileri olduğunu belirten çalışmaların yanında daha yüzeysel arkadaşlık ilişkileri (Davis, 2013) ve riskli cinsel davranışlar sergileme (Moreno, Parks, Zimmerman, Brito ve Christakis, 2009) gibi zararlı etkileri de olduğuna dair önceki bulgulara ek destek sağlamaktadır. Yakın zamanda yapılan bir çalışmada, 2012'den sonra gençler arasında artan zihinsel sağlık sorunlarının altında yatan unsurları belirleme amaciyla Twenge, Martin ve Champbell (2018), yeni medyada (sosyal medya ve akıllı telefonlar gibi elektronik cihazlar) daha fazla zaman harcayan ergenlerin zihinsel sağlık sorunlarına sahip olma olasılığının daha yüksek, sosyal etkileşim, spor/egzersiz, ev ödevi ve yazılı medya gibi ekran dışı etkinliklerde daha fazla zaman geçiren ergenlerin ise bu sorunları bildirme olasılıklarının daha düşük olduğunu belirtmişlerdir. Gelecek çalışmalar kendini nesneleştirmenin yeni medya ile ruhsal sağlık arasındaki bu olumsuz ilişkileri açıklamada yararlı olup olmadığını araştırabilir.

Eldeki çalışma, sosyal medya kullanımının alan yazında belirtilen olumlu etkileri yanında henüz benlik yapılanması tamamlanmamış ve bu yüzden diğerlerinin fikirlerine karşı aşırı hassas olan ergenlerde kendini nesneleştirme ipuçlarına maruz kaldıklarında olumsuz etkileri olabileceğini ortaya koymaktadır. Ancak bu çalışma korelasyona dayalı olduğundan çıkarımların genellenebilirliği sınırlıdır. Her ne kadar bu çalışmada sosyal medya kullanımı ve 
kendini nesneleştirmenin beğenilme arzusuyla ilişkileri artan sosyal medya kullanımıyla ilişkilendirilmiş olsa da, gözlenen ilişkilerin nedeni beğenilme arzusu ya da kendini nesneleştirme düzeyi yüksek olan ergenlerin sosyal medyayı daha sık kullanmalarına dayalı olabilir.

$\mathrm{Bu}$ çalışmanın önceki çalışmalara paralel bulguları yanı sıra bazı farklılıkları da mevcuttur. NBBÖ-genç formunun orijinal çalışması, kontrol inanc1 ölçeği çıkarıldığında modelin daha uygun indeksler sergilediğini belirtse de, bu çalışmada hem iki faktör, hem de üç faktör modeli verilerle eşit olarak doğrulandı. Bu farklılık, eldeki çalışmada negatif ifadelerin kullanılmamasından veya kültürel farklılıklardan kaynaklanıyor olabilir. Şöyle ki, zenginlik ve teknoloji seviyesi daha yüksek olan Amerika'da her geçen gün daha fazla insan estetik ameliyata sıklıkla başvurabilmekte iken, Türkiye'de henüz bu tür transformasyon norm sayılabilecek ölçüde yaygın değildir. Bu yüzden Amerika'da bireylerin değişebileceği inancı nesneleşmeden bağımsız yaygın olabilir. Gelecekteki çalışmalar bu konuya 1şık tutabilir.

Özetle, bu çalışma, NBBÖ-Genç formunun Türkiye örneklemiyle geçerliliğini ve güvenilirliğini teyit etmekte ve artan sosyal medya seviyelerinin gençlerin, başkaları tarafından beğenilme arzularının artmasıyla ilişkili olan kendini nesneleştirme seviyesini artırarak, ergenin ruh sağlığına olumsuz etkilerini sergilemektedir. Bu konunun Türk kültürü çerçevesinde çalışılması bu tür çalışmaların sıklıkla yapıldığı batı kültüründen farklı bir bağlamda kendini nesneleştirme kuramının sayıltılarının test edilmesini sağlaması açısından önem taşımaktadır. Türkiye'deki ergenler, kadınların cinselliğinin özgürce yaşanmasının büyük oranda yasaklandığı ve Müslüman kimliğinin benimsendiği bir toplumda yetişmektedir. Buna karşılık, ergenler üzerinde bireyin nesneleştirilmesine ilişkin mesajlar batı toplumlarında olduğu kadar yoğun ve belirgindir. Bu konuya ilişkin Akdağ (2011), popüler Türk ve Amerikan dergilerindeki kadın betimlemelerini kıyasladığ 1 çalışmasında Türk dergilerinde kadınların tek tip özelliklere sahip olduğunu veya Amerikan dergilerine kıyasla daha fazla cinselleşmeye maruz kaldığını bildirdi. Amerikan dergilerine kıyasla Türk dergilerinde daha fazla kadın seksi ve baştan çıkarıcı şekilde temsil edilmiştir (Türk dergileri için oran $\% 40$ ve $\% 31$ iken Amerikan dergileri için\% 33 ve\% 26). Bulgulara göre, kadının Türkiye'deki reklamlarda en yaygın rolü cinsel bir meta (\% 36) rolüdür ve bu trend Amerikan dergilerinde (\% 26) daha azdır. Geçerli ve güvenilir bir ölçüm aracı, bu çelişkili mesajların genç bireyler üzerindeki etkilerini, kendini nesneleştirme düzeylerini, kimlik ve iyilik hallerini nasıl etkilediğini ve ilgili konuları belirleme firsatı yanı sıra koruyucu faktörleri araştırmaya da olanak sağlayacaktır. Genç beyinlerin, kültürel ipuçlarının teşvik ettiği nesneleştirmeyi içselleştirmelerine yol açan mekanizmaların belirlenmesi amacıyla daha fazla çalışma yapılması ve özellikle okullarda bu baskı ortamının arkasındaki pragmatik nedenler ve bunun olumsuz etkileri hakkında farkındalık yaratma dahil olmak üzere önleyici ve iyileştirici programlarının uygulanması önerilmektedir. 


\section{Kaynakça}

Akdă̆, M. N., (2011), Türk Dergi Reklamlarındaki Kadın Rol Modeli Ve Kadın Imgesinin Amerikan Dergi Reklamları İle Karşılaştırılmalı Olarak İncelenmesi, Yüksek Lisans Tezi, İstanbul: Bahçeşehir Üniversitesi Sosyal Bilimler Enstitüsü.

Asch, S. E. (1956). Studies of independence and conformity: I. A minority of one against a unanimous majority. Psychological monographs: General and applied, 70(9), 1-70.

Barker, V. (2012). A Generational Comparison of Social Networking Site Use: The Influence of Age and Social Identity. The International Journal of Aging and Human Development, 74(2), 163-187. https://doi.org/10.2190/AG.74.2.d

Bernard, P., Legrand, S., \& Klein, O. (2018). From bodies to blame: Exposure to sexually objectifying media increases tolerance toward sexual harassment. Psychology of Popular Media Culture, 7(2), 99112.http://dx.doi.org/10.1037/ppm0000114

Breines, J. \& Crocker, J. \& Garcia, J. (2008). Self-objectification and well-being in women's daily lives. Personality \& Social Psychology Bulletin, 34, 583-98. 10.1177/0146167207313727.

Calogero, R. M. (2012). Objectification theory, self-objectification, and body image. In T. F. Cash (Ed.), Encyclopedia of body image and human appearance (Vol. 2, pp. 574-580). San Diego, CA: Academic Press.

Calogero, R. (2013). Objects don't object: evidence that self-objectification disrupts women's social activism. Psychological Science, 24, 10.1177/0956797612452574.

Calogero, R. \& Pina, A., Park, L. \& Rahemtulla, Z. (2010). Objectification theory predicts college women's attitudes toward cosmetic surgery. Sex Roles, 63, 32-41. 10.1007/s11199-010-9759-5.

Canpolat B. I, Orsel S, Akdemir A, Ozbay M. H. (2005). The relationship between dieting and body image, body ideal, self-perception, and body mass index in Turkish adolescents. International Journal of Eating Disorders, 37(2):150-5.

Cohen, R., Newton-John, T., \& Slater, A. (2017). The relationship between Facebook and Instagram appearance-focused activities and body image concerns in young women. Body Image, 23, 183-187. http://dx.doi.org/10.1016/j.bodyim.2017.10.002

Chou, C.-P., \& Bentler, P. M. (1995). Estimation and tests in structural equation modeling. In R. $H$. Hoyle (Ed.), Structural equation modeling: Concepts, issues, and applications (pp. 37-55). Thousand Oaks, CA: Sage.

Costanzo, P. R. (1970). Conformity development as a function of self-blame. Journal of Personality and Social Psychology, 14, 366- 374. doi:10.1037/h0028983

Crow, L. D., \& Crow., A. V. (1956). Adolescent Development and Adjustment. New York: McGraw-Hill Book Co.

Çuhadaroğlu, F. (1986). Adolesanlarda Benlik Saygısı, Yayımlanmamış yüksek lisans tezi, Hacettepe Üniversitesi, Sosyal Bilimler Enstitüsü, Ankara.

Davis, K. (2013. Young people's digital lives: The impact of interpersonal relationships and digital media use on adolescents' sense of identity. Computers in Human Behavior, 29, (6), 2281-2293. https://doi.org/10.1016/j.chb.2013.05.022

Doğan, T. (2010). Sosyal görünüş kaygısı ölçeği’nin (sgkö) türkçe uyarlaması: geçerlik ve güvenirlik çalışması. Hacettepe Üniversitesi Ĕ̆itim Fakültesi Dergisi, 39, 151-159.

Donner, A. \& Eliasziw, M. (1987). Sample size requirements for reliability studies. Statistics in Medicine, 6, 441-448.

Demir, R, N.K. ( 2006). The reflection of cultural changes to male and female role-models at advertisements. Firat University Journal of Social Science, 16(1), 285-304.

Erikson, E. H. (1950). Childhood and Society. W W Norton \& Co.

Festinger, L. (1954). A theory of social comparison processes. Human Relations, 7, 117-140. http://dx.doi.org/10.1177/001872675400700202

Fitzsimmons-Craft, E. E., \& Bardone-Cone, A. M. (2012). Examining prospective mediation models of body surveillance, trait anxiety, and body dissatisfaction in African American and Caucasian college women. Sex Roles: A Journal of Research, 67(3-4), 187-200.http://dx.doi.org/10.1007/s11199-0120151-5

Fredrickson, B. L. \& Roberts, T. A. (1997). Objectification theory: Towards women's lived experiences and mental health risks. Psychology of Women Quarterly, 21, 173-206. doi:10.1111/j.14716402.1997.tb00108.x 
Gapinski, K. D., Brownell, K. D., \& LaFrance, M. (2003). Body objectification and "fat talk": Effects on emotion, motivation, and cognitive performance. Sex Roles: A Journal of Research, 48(9-10), 377388. http://dx.doi.org/10.1023/A:1023516209973

Harrison, K., \& Fredrickson, B. L. (2003). Women's sports media, self-objectification, and mental health in black and white adolescent females. Journal of Communication, 53, 216-232.

Hart, T. A., Flora, D. B., Palyo, S. A., Fresco, D. M., Holle, C., \& Heimberg, R. C. (2008). Development and Examination of the Social Appearance Anxiety Scale. Assessment, 15, 48-59.

Harter, S. (1990). Identity and self development. In S. Feldman and G. Elliott (Eds.), At The Threshold: The Developing Adolescent (pp. 352-387). Cambridge, MA: Harvard University Press.

Hirschman, C., Impett, E. A., \& Schooler, D. (2006). What late-adolescent girls can teach us about objectification and sexuality. Sexuality Research \& Social Policy, 3 (4), 8-20.

Holland, G., \& Tiggemann, M. (2016). A systematic review of the impact of the use of social networking sites on body image and disordered eating outcomes. Body Image, 17, 100-110. http://dx.doi.org/10.1016/j.bodyim.2016.02.008

Hooper, D., Coughlan, J., \& Mullen, M. R. (2008). Structural equation modelling: guidelines for determining model fit. The Electronic Journal of Business Research Methods, 6, 53-60.

Hu, L. \& Bentler, P. (1999). Cutoff criteria for fit indices in covariance structure analysis: conventional criteria versus new alternatives. Structural Equation Modeling, 6, 1-55.

Impett, E. A., Henson, J. M., Breines, J. G., Schooler, D., \& Tolman, D. L. (2011). Embodiment feels better: girls' body objectification and well-being across adolescence. Psychology of Women Quarterly, 35(1), 46-58. https://doi.org/10.1177/0361684310391641

Insko, C. A., Drenan, S., Solomon, M. R., Smith, R., \& Wade, T. J. (1983). Conformity as a function of the consistency of positive self-evaluation with being liked and being right. Journal of Experimental Social Psychology, 19(4), 341-358. https://doi.org/10.1016/0022-1031(83)90027-6

Jaffe, M. L. (1998). Adolescence. New York: John Wiley \& Sons, Inc. ISBN: 0-471-57190-3.

Jöreskog, K. G., \& Sörbom, D. (2001). Lisrel 8: User's reference guide. Chicago: Scientific Software International.

Kaiser, H. F. (1974). An index of factorial simplicity. Psychometrika, 39. 31-36

Kapidzic, S., 2011. The influence of personality and internalization of media ideals on Facebook image selection. Indiana University Bloomington. Unpublished Master's thesis.

Karagöz, Y. (2016). SPSS ve AMOS 23 uygulamalı istatistiksel analizler. Ankara: Nobel Yayın.

Kaşıkara, G., \& Doğan, U. (2017). Beğenilme arzusu: ölçek geliştirme, güvenirlik ve geçerlik çalışması. Muğla Sitkı Koçman Üniversitesi Ĕ̆itim Fakültesi Dergisi, 4(2), 51-60.

Kellough, R. D., \& Kellough, N. G. (2008). Teaching Young Adolescents: Methods And Resources For Middle Grades Teaching (5th ed.). Upper Saddle River, NJ: Pearson.

Kline, P. (2000). Handbook of psychological testing. London: Routledge, https://doi.org/10.4324/9781315812274.

Lindberg, S. M., Hyde, J. S., \& McKinley, N. M. (2006). A measure of objectified body consciousness for preadolescent and adolescent youth. Psychology of Women Quarterly, 30(1), 65-76. https://doi.org/10.1111/j.1471-6402.2006.00263.x

Manago, A. M., Graham, M. B., Greenfield, P. M., \& Salimkhan, G. (2008). Self-presentation and gender on MySpace. Journal of Applied Developmental Psychology, 29, 446-458. doi:10.1016/j.appdev.2008.07.001.

McKinley, N. M., \& Hyde, J. S. (1996). The objectified body consciousness scale: Development and validation. Psychology of Women Quarterly, 20, 181-215.

Mercurio, A. E., \& Landry, L. J. (2008). Self-objectification and well-being: The impact of selfobjectification on women's overall sense of self-worth and life satisfaction. Sex Roles: A Journal of Research, 58(7-8), 458-466. http://dx.doi.org/10.1007/s11199-007-9357-3

Mehdizadeh, S.. (2010). Self-Presentation 2.0: Narcissism and self-esteem on facebook. Cyberpsychology, Behavior And Social Networking. 13. 357-64. 10.1089/cyber.2009.0257.

Meier, E.P. and Gray, J. (2014) Facebook photo activity associated with body image disturbance in adolescent girls. Cyberpsychology, Behavior, and Social Networking, 17, 199-206. https://doi.org/10.1089/cyber.2013.0305 
Moradi, B., \& Yu-Ping, H. (2008). Objectification theory and psychology of women: a decade of advances and future directions. Psychology of Women Quarterly, 32 (4), 377-398. doi:10.1111/j.1471-6402.2008.00452.x

Moreno, M. A., Parks, M. R., Zimmerman, F. J., Brito, T. E., and Christakis, D. A. (2009). Display of

health risk behaviors on MySpace by adolescents: prevalence and associations. Archives of Pediatric and Adolescent Medicine, 163, 27-34.

Moya-Garófano, A., Megías, J., Rodríguez-Bailón, R., Moya, M. (2017). Spanish version of the Objectified Body Consciousness Scale (OBCS): results from two samples of female university students / Revista de Psicología Social, 32, 1-33. 10.1080/02134748.2017.1292700.

Muehlenkamp \& Saris-Bağlama (2002); Muehlenkamp, J. J. and Saris-Baglama, R. N. (2002), Selfobjectification and its psychological outcomes for college women. Psychology of Women Quarterly, 26, 371-379. doi:10.1111/1471-6402.t01-1-00076

Noll, S. M. \& Fredrickson, B. L. (1998). A mediational model linking selfobjectification, body shame, and disordered eating. Psychology of Women Quarterly, 22, 623-636. doi:10.1111/j.14716402.1998.tb00181.x

Peat, C. M., Muehlenkamp, J. J. (2011).Self-objectification disordered eating and depression a test of meditational pathways. Psychology Of Women Quarterly, 35, 441-450.

Perloff, R.M. (2014). Social Media Effects on Young Women's Body Image Concerns: Theoretical Perspectives and an Agenda for Research. Sex Roles, 71, 363-377.

Quinn, D. M., Kallen, R. W., Twenge, J. M., \& Fredrickson, B. L. (2006). The disruptive effect of selfobjectification on performance. Psychology of Women Quarterly, 30(1), 5964.http://dx.doi.org/10.1111/j.1471-6402.2006.00262.x

Robinson, N. S. (1995). Evaluating the nature of perceived support and its relation to perceived self-worth in adolescents. Journal of Research on Adolescence , 5 (2), 253-280.

Rosenberg, M. (1965). Society and the adolescent self-image. Princeton, NJ: Princeton University Press.

Scales, P. C. (2010). Characteristics of young adolescents. In This we believe: Keys to educating young adolescents (pp. 63-62). Westerville, OH: National Middle School Association.

Schaefer, L. \& Thompson, J. (2018). Self-objectification and disordered eating: a meta-analysis. International Journal of Eating Disorders, 51, 10.1002/eat.22854.

Sherman, L. E., Payton, A. A., Hernandez, L. M., Greenfield, P. M., \& Dapretto, M. (2016). The power of the Like in adolescence: Effects of peer influence on neural and behavioral responses to social media. Psychological Science, 27(7), 1027-1035. https://doi.org/10.1177/0956797616645673

Steinberg, L.A. (2008). Social neuroscience perspective on adolescent risk-taking. Developmental Review, 28, 78-106. http://dx.doi.org/10.1016/j.dr.2007.08.002

Steinberg, L. (2014). Age of opportunity. Lessons from the new science of adolescence. Mariner Books, Boston, Newyork.

Strelan, P., \& Hargreaves, D. (2005). Women who objectify other women: The vicious circle of objectification? Sex Roles, 52, 707-712. doi: 10.1007/s11199-005-3737-3.

Sveningsson Elm, M., 2007. Doing and undoing gender in a Swedish Internet community. In: Sveningsson Elm, M., Sundén, J. (Eds.), Cyberfeminism in Northern lights. Gender and digital media in a Nordic context. Cambridge University Press, Cambridge, UK. http://urn.kb.se/resolve?urn=urn:nbn:se:kau:diva-18434 (accessed 19.1.14).

Tabachnick, B. G., \& Fidell, L. S. (2001). Using multivariate statistics (4th ed.). Needham, MA: Allyn \& Bacon.

Tiggemann, M., \& Slater, A. (2014). NetTweens: The Internet and Body Image Concerns in Preteenage Girls. The Journal of Early Adolescence, 34(5), 606-620. https://doi.org/10.1177/0272431613501083

Tolman, D. L., Impett, E. A., Tracy, A. J., \& Michael, A. (2006). Looking good, sounding good: Femininity ideology and adolescent girls' mental health. Psychology of Women Quarterly, 30(1), 8595. http://dx.doi.org/10.1111/j.1471-6402.2006.00265.x

Twenge, J. M., Martin, G. N., \& Campbell, W. K. (2018). Decreases in psychological well-being among American adolescents after 2012 and links to screen time during the rise of smartphone technology. Emotion, 18(6), 765-780.

Yağmurcu, Y. ve Tosun, L. P. (2018). Nesneleştirilmiş Beden Bilinci Ölçeği'nin Türkçeye uyarlanması ve psikometrik özelliklerinin incelenmesi. Nesne Psikoloji Dergisi (NPD), 6(13), 225-255. DOI: 10.7816/nesne-06-13-01 
Verduyn, P., Lee, D. S., Park, J., Shablack, H., Orvell, A., Bayer, J., . . . Kross, E. (2015). Passive Facebook usage undermines affective well-being: Experimental and longitudinal evidence. Journal of Experimental Psychology: General, 144(2), 480-488. 


\section{Extended Abstract}

\section{Introduction}

Self-objectification advanced by Fredrickson and Roberts (1997) refers to individuals' internalization of others' values and expectations based on the belief that an individual's value comes from her/his sexual attractiveness. According to the self-objectification theory, society, which is rich with the implicit and explicit suggestions that a woman is valued for her beauty and attractiveness, teaches young girls that their body is subjected to others' evaluations and criticisms as a pleasure tool. Because of the internalization of these values, the individual becomes to function as her own third eye, self-forcing upon these values regarding a person's value comes from her appearance, thinness, and sexual attractiveness, even in the absence of any external pressure. Fredrickson and Roberts argue that with a self-imposed constant pressure to be attractive all the time, person's main focus becomes to be beautiful and presentable to others over everything else, leaving less available resources for intellectual, emotional and sexual freedom. The existing studies linked self- objectification to a variety of negative outcomes including eating disorders such as bulimia and restrictive eating, well-being, selfesteem, dissatisfaction with the body, intent to have plastic surgery in near future and depression. One way to reduce its negative effect is gaining knowledge to determine the conditions in which it is most disruptive along with empowerment of young girls by raising awareness on the topic. Yet, there is no valid instrument to evaluate the current situation in Turkey for adolescents and pre-adolescents. The purpose of this study is to adopt an instrument to measure the level of self-objectification of Turkish pre-adolescents. In the literature, there are two commonly used instruments. The Self-Objectification Questionnaire (SOQ) developed by Noll and Fredrickson and the Objectified Body Consciousness Scale (OBCS) developed by McKinley and Hyde. Although both tools are considered as valid and reliable measurement tools, only OBSC has a modified version to assess self-objectification levels of preadolescent and adolescents. This study aims in adapting OBC-Youth Scale for Turkish pre-adolescents.

In addition to test validity and reliability of the OBC-Youth Scale in Turkish, this study aims to test whether self-objectification plays a mediating role in the relationship between social media use and desire for being liked. Since an important part of the social media consists of youth's postings of their best, even usually distorted and enhanced pictures of themselves, in this study, it is expected that increasing social media use by youth would lead higher levels of need to be approved by others and self-objectification. Finally, it is expected that a part of increasing levels of desire to be liked due to social media usage would be through increasing 
levels of self-objectification which is marked by the needs of being beautiful and presentable to others all the time.

\section{Method}

The study consists of two parts: The first part consists of adaptation process and the second part consist of test of mediating role of self-objectification in the relationship social media use frequency and desire to be liked. Further, the first part of the study consists of two stages: pilot study and the validity and reliability analysis of the scale. Two pilot studies with 97 middle school students established the questionnaire's structure. Then, 457 middle school students were administered Self-Objectification Questionnaire- Youth Scale (SOQ-Youth), Social Appearance Anxiety Scale and Rosenberg Self Esteem Scale in order to test questionnaire's validity and reliability. Since three of the data was excluded because either the participant did not report gender or the age of the student was beyond adolescent years, analysis were done with the data obtained a total of 554 students. Finally, additional 164 middle school students took desire to be liked scale along with SOQ-youth and items to measure social media usage and demographic variables.

\section{Results}

Analysis demonstrated a 3 factor solution with eigenvalues greater than 1. All items loaded theoretically linked factors. These 3 factors accounted for $\% 59$ of the total variance. The reliability scores of control beliefs, body shame and self-surveillance subscales were $.72, .81$ and .82 , in order. Also, the scales had significant correlations with criterion variables of social appearance anxiety and self-esteem.

\section{Discussion}

The current study designed to adapt Objectified Body Consciousness Scale-Youth form in to Turkish to test the extent and scope of these influences on developing young's personality and behaviors within the framework of model's predictions with culturally very different population. In Turkey, although self-objectification clues are abundant, incompatible opposite standards and roles are also equally forced by the society such as encouragement of being sexually passive, virtuous and emphasizing the role of motherhood over every other role a female could endorse. These clues might act as protective against both social and printed media's constant selfobjectification clues or vice versa, contradictory messages presented to youngsters spontaneously might have even more evident negative effects on Turkish adolescents compare to their western peers. The current study's results confirm the validity and reliability of OBC- 
Youth form for Turkish pre-adolescents and contributes to the literature by providing a valid and reliable measurement tool in studying these issues.

In addition to confirming statistical characteristics of the OBC-Youth scale, this study tested the correlation between social media use, self-objectification and desire to be liked. Although media use predicted desire to be liked, when self-objectification component entered to the regression, social media use was no longer related to desire to be liked indicating higher levels of social media use by youth is related to self-objectification which in turn correlated to higher levels of desire to be liked. Besides, this pattern was much more salient for girls, consistent with theoretical postulates. For boys, although social media use was not related to higher levels of desire to be liked, both body surveillance and body shame was predictive of desire to be liked, probably because different motives govern girls' and boys' social media use. Previous studies demonstrated that while girls are more likely to aim to develop friendship ties by posting photographs of themselves with friends, boys are more likely to post pictures through social media that include technology, sports and humor. Others reported that both female and male young participants perceive that girls are more likely to select pictures emphasizing their attractiveness than boys. These results suggest that although both girls and boys selfobjectification is related to increasing levels of desire to be liked by others, social media use is more effective on girls' internalization of objectification of woman. 